\title{
ON THE PRODUCTION OF LIVING MATTER IN THE SEA OFF PLYMOUTH
}

\author{
By H. W. Harvey, Sc.D., F.R.S. \\ Hydrologist at the Plymouth Laboratory
}

\author{
(Text-figs. I-IO)
}

\begin{tabular}{|c|c|c|c|c|c|c|c|}
\hline \multicolumn{8}{|c|}{ CONTENTS } \\
\hline \multirow{2}{*}{\multicolumn{8}{|c|}{$\begin{array}{l}\text { The phytoplankton } \\
\text { Methods of estimation }\end{array}$}} \\
\hline & & & . & $\cdot$ & . & . & $\begin{array}{l}900 \\
100\end{array}$ \\
\hline The standing crop of phyt & toplanktor & & . & . & & $\cdot$ & 104 \\
\hline The annual production of & phytoplar & akton & & & & $\cdot$ & 106 \\
\hline the annu: & al produc & ion 0 & 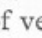 & getation & & & 108 \\
\hline he zooplankton community & & - & . & . & . & . & II 2 \\
\hline Foo & & - & . & . & & . & II 6 \\
\hline opulation & a density & ${ }^{-}$ & & . & . & . & 120 \\
\hline elagic & . & . & . & . & . & 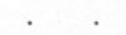 & 122 \\
\hline ension & . & ( & . & . & . & - & 124 \\
\hline Deme & . & & & . & - & . & I25 \\
\hline 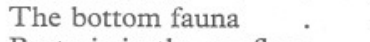 & & & & . & & r & \\
\hline sea floor & & & & . & & . & I 28 \\
\hline o the guantity of orang & as presen & and & & daily fo & food rec & irements & I 29 \\
\hline$f$ changing fertilit & & & & . & & . & 132 \\
\hline bliography & & & & 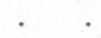 & & . & 136 \\
\hline
\end{tabular}

A study, now in progress, of the phosphorus cycle in the sea off Plymouth required some knowledge of the amount of plants and of several ecological groups of animals. There were no existing data except for zooplankton and the larger net-caught phytoplankton.

From information supplied by friends and colleagues, it was possible to make tentative estimates of the average biomass of other groups of animals occurring below unit area of the sea.

Although some of these estimates are derived indirectly and are indeed tentative, together they provide a framework on which to compute the food supply and food requirements of the animal population. There results a picture, crude and in part indefinite, of the quantitative relations between the different ecological groups and of how change of circumstance may affect the populations. It is the aim of this essay to present this picture.

The help of many friends and colleagues is gratefully acknowledged, both in supplying information and in amending drafts of this essay. To Mr P. G. Corbin and Mr P. S. B. Digby, who collected, sorted and weighed hauls of plankton in June 1947, and to Dr L. H. N. Cooper, who collected many samples for me, I am further indebted. 


\section{The Phytoplankton}

The great difference in size of the various species which make up the community in these seas is perhaps more striking than the diverse shape of the different species.
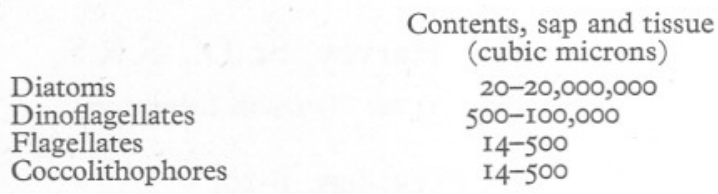

Even among individuals of the same species, notably in species of diatoms, there are very considerable differences in size. Thus a large individual of Ditylum Brightwellii may have a volume of one to two million cubic microns and a small individual of fifty thousand-a thirty-fold difference in size within the same species.
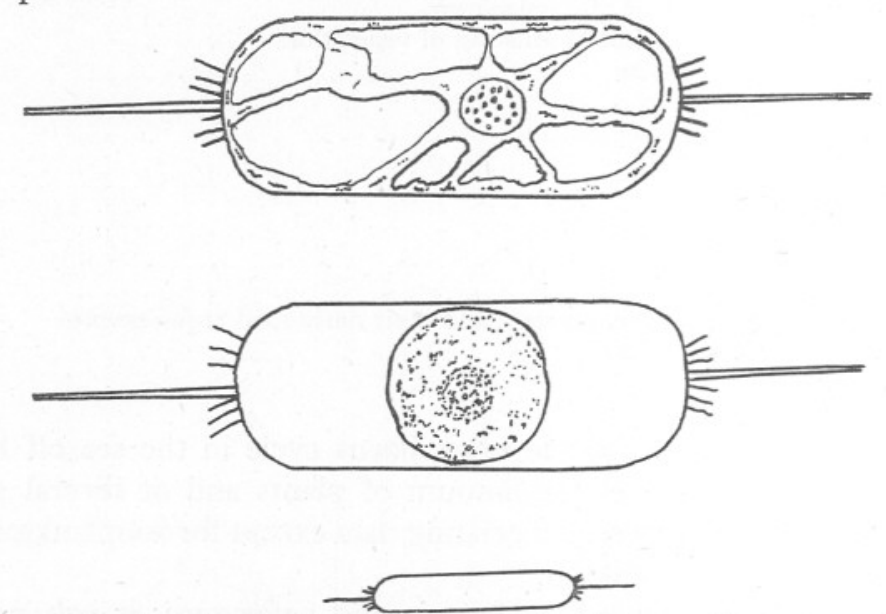

Fig. I. Cells of Ditylum Brightwellii. Large cells about $90 \mu$ diameter, small cell I5-20 $\mu$ diameter. (After Gross, 1937.)

Normally these plants are considered in terms of their linear dimensions; but the cubic dimensions of their cell contents will give a better measure of each individual's value as food for other organisms.

In some species the cells appear well filled with living tissue; in other species there is more sap than tissue. Thus, in Ditylum, the protoplasm normally lines the inside of the cell and projects as a network through the watery sap. It readily responds to stimulus, such as a fall in temperature, by rounding into a ball. It is then seen to occupy only a quarter of the cell content.

Given a suitable intensity of light, and a sufficient supply of dissolved nitrogen and phosphorus compounds in forms which they can absorb, these plants are capable of very rapid growth. Thus, Braarud (1945) has observed that some of the smallest plants double in numbers every $5 \mathrm{hr}$., while larger 
species required Io-75 hr. The optimum light intensity and temperature also differ for different species.

One of the earliest and most illuminating experiments on the rate of growth was made by Gaarder \& Gran (1927) in the following manner. Water was collected on 22 March from Oslo Fiord, the population density of the dominant species determined, and the water then put into flasks which were hung at different depths in the fiord. The temperature was $\mathrm{I} \cdot 8^{\circ} \mathrm{C}$. After 3 days, on the 25 th, the population density was again determined.

\begin{tabular}{cccc} 
Depth & \multicolumn{3}{c}{ Percentage increase in $24 \mathrm{hr}}$. \\
(m.) & $\begin{array}{c}\text { Lauderia } \\
\text { glacialis }\end{array}$ & $\begin{array}{c}\text { Thalassiosira } \\
\text { gravida }\end{array}$ & $\begin{array}{c}\text { Thalassiosira } \\
\text { Nordenskioldii }\end{array}$ \\
0 & 77 & 59 & I0 \\
2 & 79 & 58 & 73 \\
5 & 70 & 55 & 67 \\
I0 & 28 & 34 & 23 \\
20 & 0 & 0 & 0
\end{tabular}

Compared with conditions in the English Channel at the end of March, this fiord water is $6-7^{\circ} \mathrm{C}$. colder, less transparent, but richer in nutrient salts. It is notable that optimum growth took place in the upper $5 \mathrm{~m}$., whereas off Plymouth and the Firth of Clyde in summer the optimum probably lies at about ro m. depth, due to greater transparency of the water.

Several experiments have shown that if water is collected off Plymouth at about this season of the year, and kept at room temperature in a flask in a north window, where the intensity of light is similar to that at some ro $\mathrm{m}$. depth in the sea, the plant cells proliferate and use up the available nutrient salts within a few days. If the nutrient salts are increased ten-fold and the water is kept aerated, within about I4 days they are all utilized by the plants and a crop is produced having the same species constitution, but very many times denser, than that which appears in the sea at the time of the phytoplankton maximum. In some experiments it was found necessary also to add iron in an available form in order to ensure complete utilization of the nutrients.

Another characteristic of these unicellular plants is their high proportion of protein and fat when their organic content is compared with that of land plants. Various analyses of marine diatoms collected from the sea show 30$40 \%$ of protein and 7-10\% of lipoids in their tissue. Recent analyses by Ketchum \& Redfield (I949) of a number of unicellular algae, mostly fresh water, grown in artificial light, showed that composition of their organic matter was surprisingly similar: protein, $4 \mathrm{I}-54 \%$; carbohydrates, 20-38\%; lipoids, $20-27 \%$.

These algae were grown in water containing a plentiful supply of available nitrogen and phosphorus, and of carbon dioxide. Under conditions where either available nitrogen was deficient or both nutrients were deficient, the plants contained a smaller proportion of protein. 
These various analyses show that marine phytoplankton has a remarkably high food value for animals. The protein content of the plants and the rapidity with which they can grow are outstanding features.

\section{Methods of estimation}

Owing to the great difference in size of the individual organisms comprising the plant community, it is a matter of practical difficulty to determine the population density or standing crop of plants per unit area of the sea. Catches made by net, either hauled vertically through the whole column of water or towed horizontally at various depths, collect a proportion of the organismsa proportion which varies greatly with time and position. Concentration of the plants in a sample of water, by sedimentation, centrifuging, or by filtration through a membrane, and counting the individuals has been extensively employed. In order to arrive at the quantity or volume of plant tissue in the organisms, measurements of individuals, often of complicated shape, are needed, and small errors in linear measurements cause large errors in the estimate of volume. Moreover, the proportion of plant tissue in cells containing vacuolar sap is difficult (or even impossible) to gauge. Counting and measurement require much time. Unless the results can be expressed in terms of quantity of plant tissue they do not give a direct measure of the food value of the standing crop to the animal dependent on it for food.

In order to obtain the numerous observations necessary to assess the everchanging crop, an indirect method has been rather extensively employed. The approximate quantity of chlorophyll in the plants can be quickly determined; it does not provide a direct linear measure of the organic matter in the plants, but it is perhaps as good an overall measure as could be obtained by any other method and allows numerous observations. In addition to providing a rough measure of the vegetable organic matter, experiments by Gessner indicate that it provides a direct measure of the capability of the plants to produce organic matter. He kept waters from a number of Bavarian lakes, having different phytoplankton floras, in the same light intensity at the same temperature. The quantity of chlorophyll in the phytoplankton showed a near relation to the assimilation which took place in unit time in the water from eleven lakes out of thirteen (Fig. 2). Hence the quantity of chlorophyll in the water gives a measure of the capacity or potentiality of the plants contained in it to produce vegetable food for the animal population.

In using chlorophyll determinations to compute the quantity of vegetable organic matter in the sea, two operations are involved which need consideration-there is the technique of estimating the chlorophyll in the plants filtered from a sample of sea water, and, having determined the quantity of chlorophyll in the plants below a unit area of the sea, there remains how best to gauge from it the quantity of vegetable tissue in which it had existed.

Chlorophyll occurs in algae as a mixture of chlorophyll $a$ and chlorophyll $c$ 
(chlorofucin), always in conjunction with carotinoid pigments, largely fucoxanthin. The yellow carotinoids and the green chlorophylls leach out from the plants into $80 \%$ acetone, or into alcohol. Whichever solvent is used, substantially the same depth of green colour results, and this green colour has the same tint or hue whether it is extracted from diatoms, fucoid sea weeds or a common golden brown flagellate. Hence the proportion of chlorophylls to carotinoids is similar.

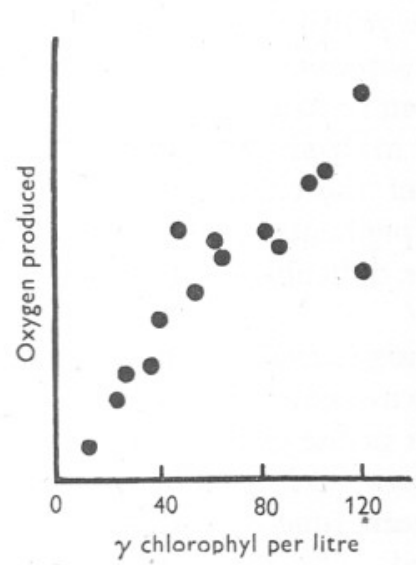

Fig. 2.

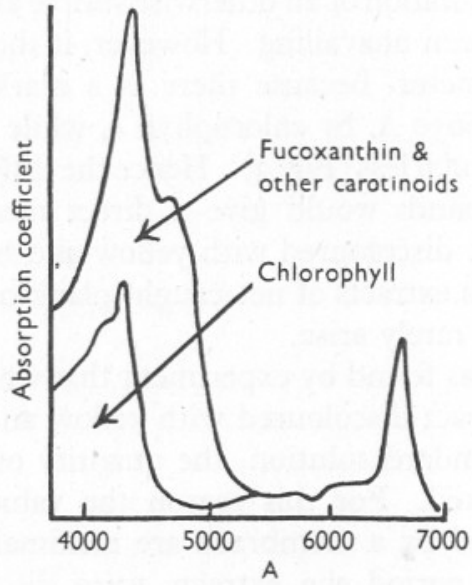

Fig. 3 .

Fig. 2. Relation between assimilation and chlorophyll content of waters from thirteen Bavarian lakes. (After Gessner, 1943.)

Fig. 3. Absorption spectra in acetone of the pigments in the diatom Nitzschia closterium. (After Dutton \& Manning, I94I.)

In consequence, these extracts can be matched visually against a stable and reproducible green standard solution. This is more yellowish green than a solution of pure chlorophyll; it can be evaluated against chlorophyll solution to which a yellow has been added to assist colour matching. To do this exactly would entail a pure preparation of chlorophylls $a$ and $c$ in the proportion in which they occur in algae. It is not necessary for our purpose to express the colour in terms of chlorophyll concentration because the depth of yellow-green colour in the extract is directly proportional to the green chlorophyll in it, provided it matches in tint or hue the permanent standard. Then the colour of the extract can be expressed in arbitrary units, proportional to its chlorophyll content and proportional to the concentration of the permanent standard. ${ }^{1}$

1 A permanent standard which is in use consists of a mixture of nickel sulphate and potassium chromate in dilute acid, the quantity containing $4.6 \times 10^{-6} \mathrm{~g}$. $\mathrm{NiSO}_{4} 6 \mathrm{H}_{2} \mathrm{O}$ and $25 \times 10^{-6} \mathrm{~g}$. $\mathrm{K}_{2} \mathrm{CrO}_{4}$ being taken as containing one arbitrary unit of yellowish green pigment (one U.P.P.). A green permanent standard has been matched with a mixture of pure chlorophyll $a$ and $b$ by Guthrie; when more yellow is added to this green standard, the quantity matching one U.P.P. is that which, without added yellow, matches a solution containing $c .0 .003 \mathrm{mg}$. of chlorophylls $a$ and $b$. 
When the plankton is filtered from sea water and extracted with solvent, the solution is often an exact match in tint or hue as well as in depth of colour with a suitable dilution of the permanent yellow-green standard. At other times the residue after filtration contains detritus and pigmented animals from which yellow or brown pigments dissolve. Then all that can be done is to guess the dilution of the permanent standard which contains about the same degree of green colour. Such aguessed estimate may be very inexact. Attempts to overcome this limitation of an otherwise simple and rapid technique with simple apparatus have been unavailing. However, it should be possible with a sensitive spectrophotometer, because there is a marked absorption of light of wave-length $655^{\circ}-6650 \mathrm{~A}$. by chlorophyll $a$, while between 6200 and $6300 \mathrm{~A}$. absorption is very much less (Fig. 3). Hence the difference in absorption by light of these two wave bands would give a direct measure of the chlorophyll content of an extract discoloured with yellow and brown pigments.

With extracts of net-caught plankton these difficulties of assessing the green colour rarely arise.

It was found by experiment that when trying to evaluate the green colour in an extract discoloured with yellow and brown pigments, by comparison with the standard solution, the quantity of green in the extract was usually overestimated. For this reason the values shown in Fig. 4 for phytoplankton retained by a membrane are maximal between June and September, during which period the extracts were discoloured. The probability of an overestimate during this period is indicated in Fig. 4 by a series of dots below the value actually estimated.

The ratio of chlorophyll to organic matter doubtless varies between algae of different species, and varies in any one species with the quantity of reserve material which has been laid down-diatoms are known to form droplets of free fatty acids in their cytoplasm, usually when growing slowly. Furthermore, when diatoms are grown in a dim light they appear browner and may contain a greater proportion of chlorophyll than when grown in a brighter light. However, if representative samples of phytoplankton are taken from whole water columns, and consist of many species, these differences in the ratio will tend to even out.

Data concerning this ratio of chlorophyll to organic matter, both direct and indirect, are sparse, but suffice to give a rough value of its magnitude.

On several occasions net hauls from bottom to surface in the sea off Plymouth have yielded catches consisting of diatoms with few zooplankton organisms, most of which could be separated from the catch. Analyses of these showed that diatoms containing one U.P.P. contained 0.00013 and $0.00010 \mathrm{mg}$. of phosphorus. Diatoms collected in the Gulf of Maine have been analysed by both Redfield and by Waksman; the mean value of their analyses show a ratio of $\mathrm{C}: \mathrm{N}: \mathrm{P}$ equal to $\mathrm{I00}: \mathrm{I6}: \mathrm{I} \cdot 67$. This indicates that their organic matter consisted of some $47 \%$ protein and $53 \%$ carbohydrates and lipoids, and con- 
tained $0.75 \%$ of phosphorus. Combining this value with that relating green colour to phosphorus content, the result indicated that diatoms containing one U.P.P. of green colour contained $0.0135-0.0175 \mathrm{mg}$. of dry organic matter. These deduced quantities of organic matter may be low, because the diatoms analysed for their C: N : P ratio were collected in the Gulf of Maine where the water is richer in phosphate than in the English Channel. Experiment has shown that diatoms grown in low concentrations of phosphate tend to contain less in proportion to their organic content. ${ }^{1}$

A culture of a brown chrysomonad flagellate was analysed by the writer. The quantity of this which contained one U.P.P. of green pigment was found to contain $0.0094 \mathrm{mg}$. of organic matter by loss on ignition. This value is probably too low, since the rather violent centrifuging necessary to concentrate the flagellates caused some to disrupt, discharging soluble organic matter into the water.

These estimates point to a mixed community, growing at all depths in the nutrient poor waters of the English Channel, containing about $0.016 \mathrm{mg}$. dry ash-free organic matter per unit of green colour or one U.P.P. This estimated ratio is no more than a rough approximation. It is unlikely to be less than half or more than double the true mean ratio. Rather many practical difficulties need to be overcome in order to improve this rough approximation.

A number of net catches consisting of diatoms, often with other plankton organisms, from the surface water of the Gulf of Maine have been examined by Riley (I94I). From a regression equation it was found that diatoms containing one U.P.P. of green colour contained, on the average, $0.035 \mathrm{mg}$. of dry organic matter. This value may be higher than for a representative sample from all depths since the diatoms were collected from the surface layer. Various observations in the past, and a rough experiment by the writer, suggest that diatoms contain less pigment when grown in strong light than when grown in dim light, but further experiment is necessary to determine whether the light intensity affects the ratio of chlorophyll to organic matter in the diatoms.

1 In addition to the classic observations by Ketchum on the marine diatom Nitzschia closterium, Redfield \& Ketchum (I949) found that the fresh-water alga, Chlorella pyrenoidosa, grown in artificial light, accumulated much less phosphorus when grown in a phosphate-poor medium.

In culture rich in phosphate and nitrate, algae contained $2.69 \%$ of their dry weight as phosphorus.

In culture deficient in phosphate and nitrate, algae contained $\mathrm{I} \%$ of their dry weight as phosphorus.

In culture rich in nitrate, deficient in phosphate, algae contained $0.59 \%$ of their dry weight as phosphorus.

In culture rich in phosphate, deficient in nitrate, algae contained $\mathrm{I} \cdot 8 \%$ of their dry weight as phosphorus.

It is of interest that the protein-carbohydrate-lipoid ratios in the organic matter of several fresh-water unicellular algae were very similar to that of a marine diatom grown under similar cultural conditions. 


\section{The Standing Crop of Phytoplankton}

During 1949 a position 5 miles seaward from Plymouth, having $50 \mathrm{~m}$. depth of water, was sampled at intervals. Hauls with a net of fine bolting silk, having, when wet, meshes with pores of $4 \mathrm{I} \times 52 \mu$, were made through the whole water column from surface to bottom; the quantity of water filtered being registered by a meter in the mouth of the net. The catches were extracted with solvent and the green colour estimated. The result is shown in Fig. 4. It shows similar seasonal variations but lesser quantities than found in a series of observations made in exactly the same manner throughout 1933 and I934.

At the same time, equal quantities of water, collected from 5, I5, 25, 35 and $45 \mathrm{~m}$. depth, were mixed to give a composite sample representative of the whole water column. Two-litre portions of the composite samples were filtered through a small disk of Whatman no. 2 filter-paper under a head of $2-3 \mathrm{~cm}$. of water. The residue was extracted with solvent and the depth of green colour determined. From observations in Long Island Sound, Riley had concluded that this filter-paper held back $90 \%$ or more of the phytoplankton organisms, little more being held back by a membrane filter. On and after 26 April filtration through a Gradocol membrane, average pore diameter $0.9 \mu$, was adopted. Extracts of the phytoplankton collected on filter-paper contained less green than extracts collected on the membrane.

$\begin{array}{ccc}\text { Composite sample } & \begin{array}{c}\text { Green colour, expressed in } \\ \text { B.P.P. per cubic metre of water }\end{array} \\ \text { collected } & \begin{array}{c}\text { By filtration } \\ \text { through paper }\end{array} & \begin{array}{c}\text { By filtril } \\ \text { through membrane }\end{array} \\ 7 \text { May } & 7,500 & \text { I2,000 } \\ \text { I I,000 }\end{array}$

On both occasions the water contained many small flagellates. The tint or hue of the extract was similar to that of the nickel standard.

At the end of May a notable quantity of organic detritus had accumulated in the water; and from then until August the extracts were seriously discoloured with yellow-brown pigments.

Provided the depth of water exceeds the depth of the photosynthetic zone, it is of interest to compare the standing crop of phytoplankton below unit area of the sea at different positions. The mean value of a number of observations made in the Gulf of Maine on seven occasions are plotted in Fig. 5. Water samples had been filtered through. Whatman no. 2 filter-paper and the green pigment extracted from the residues was estimated. It is seen that in that sea-area, where the nutrient-salt content is over three times greater than during recent years in the English Channel, the chlorophyll in the plants below a square metre is considerably greater than in the water off Plymouth. 


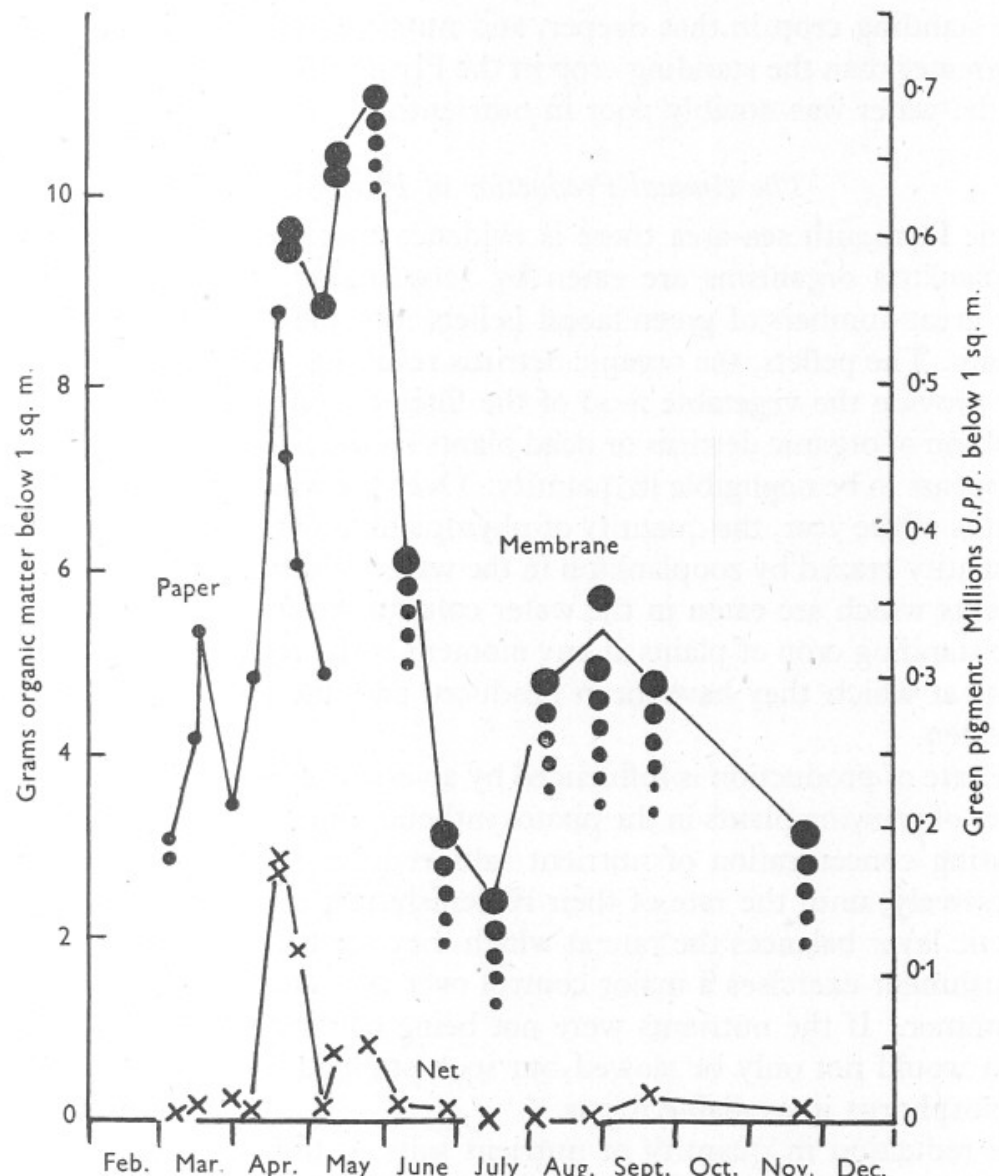

Fig. 4. The quantity of green pigment and the (calculated) quantity of organic matter in the phytoplankton at a position 5 miles seaward from Plymouth during I 949.

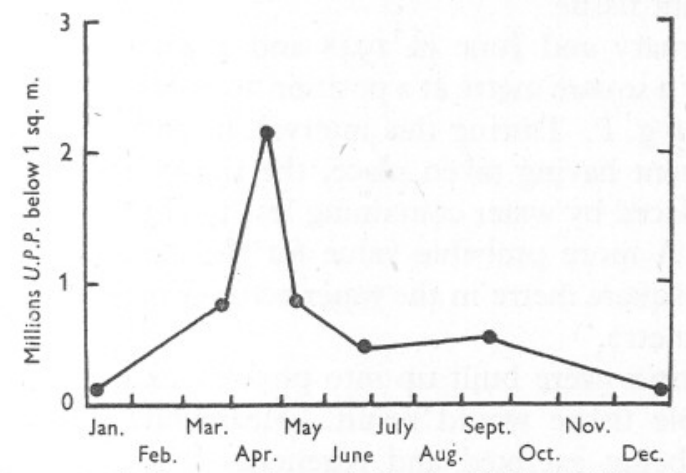

Fig. 5. Phytoplankton population on George's Bank, Gulf of Maine, in terms of units of plant pigment below a square metre. (After Riley, 1946.) 
The standing crop in that deeper, and nutrient-rich, sea-area is about five times greater than the standing crop in the Plymouth area during 1949-a year when the water was notably poor in nutrients.

\section{The Annual Production of Phytoplankton}

In the Plymouth sea-area there is evidence that the majority of the larger phytoplankton organisms are eaten by zooplankton organisms. These discharge great numbers of green faecal pellets into the water when plant life is abundant. The pellets, the organic detritus resulting from them, and some few plants provide the vegetable food of the filter-feeding bottom-living animals. Deposition of organic detritus or dead plants on the floor of the open sea in this area appears to be negligible in quantity. Over the whole year, or over the first 6 months of the year, the quantity of phytoplankton produced approximates to the quantity grazed by zooplankton in the water column. Yet only a portion of the plants which are eaten in the water column are fully digested.

The standing crop of plants at any moment is the resultant balance between the rate at which they have been produced and the rate at which they have been eaten.

The rate of production is influenced by an array of factors, in addition to the number of growing plants in the photosynthetic zone. As the year advances the decreasing concentration of nutrient salts reduces the rate of multiplication progressively, until the rate of their replenishment in the water of the photosynthetic layer balances the rate at which they are being utilized. This rate of replenishment exercises a major control over the monthly production during the summer. If the nutrients were not being continuously replenished plant growth would not only be slowed but soon stopped through lack of nitrogen and phosphorus in available forms.

The reduction in quantity of nutrient salts in the water column between winter and summer is readily determined. This quantity, plus that which has been excreted by the animals or otherwise reformed, has meanwhile been built up into plant tissue.

Between February and June in 1948 and again in 1949, the decrease in phosphate below a square metre at a position 20 miles off-shore from Plymouth amounted to $0.49 \mathrm{~g}$. P. During this interval, in both years, there is evidence of water movement having taken place, the richer water present in January having been replaced by water containing less total phosphorus (Armstrong \& Harvey, 1950). A more probable value for the decrease in phosphate since January below a square metre in the water actually present in June is $0.40 \mathrm{~g}$. P below a square metre.

If these quantities were built up into phytoplankton some $53-65 \mathrm{~g}$. of dry ash-free vegetable tissue would result. Meanwhile, during the 5 months, phosphate was being excreted and regenerated in the water and this also utilized by plants. The $53-65 \mathrm{~g}$. of vegetable tissue is an estimate of the 
minimum quantity of plant tissue produced; in all probability it was greatly exceeded. ${ }^{1}$

Minimal estimates of production during the first half of the year have been made by Atkins (1928) and by Cooper (I933) in previous years, from the decrease in phosphate, in nitrate, in carbon dioxide and from the increase in dissolved oxygen. The values range from 85 to $190 \mathrm{~g}$. of organic matter in the 6 months.

During the second half of the year the standing crop is less. In addition, the low concentration of nutrients slows the plants' growth rate. It is not until after mid-September that any material increase in nutrients occurs in the upper layers. By this time the quantity of light is half that in summer and is falling rapidly (Fig. 6). Thus, there is almost certainly less production during the second half of the year.

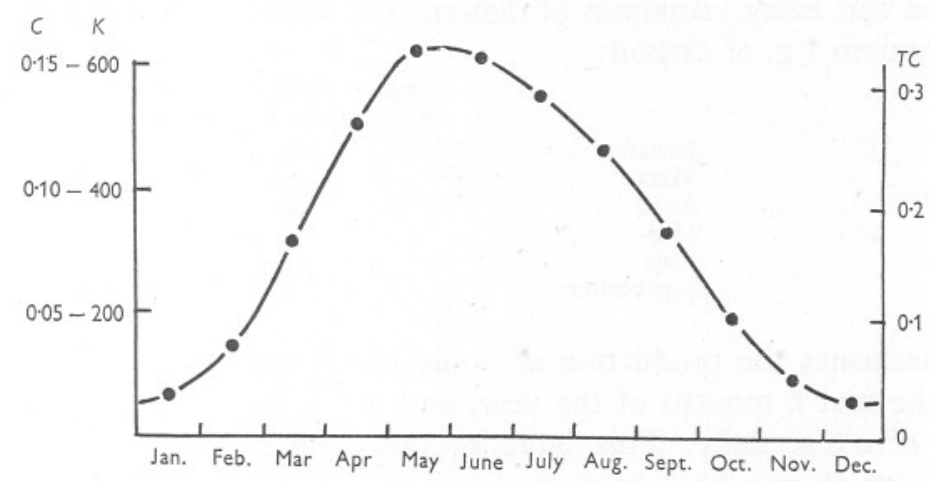

Fig. 6. Average illumination at Plymouth for the years $1930-37$. K, kilolux hours per day; $C$, gram calories per $\mathrm{cm} .{ }^{2}$ per min., both for light within the range $380-720 \mathrm{~m} \mu$ wavelength. $T C$, deduced total solar radiation, which includes infra-red, in g./cal. per cm. ${ }^{2}$ per min. (From data by Atkins, 1938.)

These various considerations and minimal half-year estimates provide reason to expect that the total production throughout the whole of 1949 is unlikely to have fallen short of $120-200 \mathrm{~g}$. of organic matter below a square metre (an average of $0.4-0.55 \mathrm{~g}$. daily), and may have been considerably more.

It is of interest to compare this assessment of the annual production of organic matter by plants in this nutrient-poor area with an assessment based on entirely different premises in another sea area.

1 Observations made in this area and in Loch Striven suggest that during March the diatom population in the whole water column divides on the average once in $36-38 \mathrm{hr}$., with the production of 50-70\% of its own weight of organic matter daily. From Fig. 6 it is seen that the incident light in March is roughly the average of that for the period January to June; the temperature is rather less than the average over this period. On the other hand, during April and May the concentration of nutrients in the upper layers falls rapidly. Hence for the first 5 months of the year there is suggested a daily production of rather less than $50 \%$ of the biomass of the standing crop. If a value of $30 \%$ daily is assumed, and the mean biomass over the first 5 months is $5-6 \mathrm{~g}$. organic matter below a square metre (Fig. 4), then the production during this period amounts to $250-300 \mathrm{~g}$. 
A very rough assessment of the whole annual production of phytoplankton in the Gulf of Maine has been made by Riley in the following way. Transparent and black bottles were filled with the water, kept at sea temperature in a barrel of water for one or more days and the resulting difference in oxygen content of the light and dark bottles determined. This difference gives a direct measure of the gross production by the plants, that is the quantity of carbon synthesized, and takes no account of their losses meanwhile by respiration. The latter were calculated from the estimated quantity of plant life in the water and subtracted from gross production. From the depth of the photosynthetic zone, month by month, in the area and the relative light intensities, the carbon synthesized below a square metre was roughly estimated. In the following table, the quantity of organic matter has been substituted for the quantity of carbon, to make these readily comparable with the quantities already considered in this essay. Analyses of diatoms had shown that $2.24 \mathrm{~g}$. of organic matter contain I $\mathrm{g}$. of carbon:

\begin{tabular}{|c|c|}
\hline & $\begin{array}{l}\text { Organic matter produced } \\
\text { below I } .^{2} \text { in g. per day }\end{array}$ \\
\hline January & -0.112 \\
\hline Marcl & +0.425 \\
\hline April & $2 \cdot I$ \\
\hline May & $1 \cdot 2$ \\
\hline une & $\mathrm{I} \cdot 4$ \\
\hline September & 0.31 \\
\hline
\end{tabular}

This indicates the production of some $160 \mathrm{~g}$. organic matter below $\mathrm{I} \mathrm{m} .^{2}$ during the first 6 months of the year, and $270 \mathrm{~g}$. during the whole year, an average of $0.8 \mathrm{~g}$. daily. This includes the organic matter produced from nutrients which may have been used, excreted and used again.

\section{Factors Affecting the Annual Production of Vegetation}

Having considered the sequence of plant life and the quantities involved, it is of interest to consider the major factors which determine the annual production of vegetable tissue.

The production taking place at any moment is the quantity of the standing crop, multiplied by its mean rate of multiplication. Only those cells can grow which lie within the photosynthetic zone.

The quantity or size of the standing crop varies as it is either reduced by being eaten or is allowed to increase. Increase occurs when production exceeds losses due to grazing and losses due to respiration of those phytoplankton cells which are carried or sink below the compensation level, where they dwindle, being no longer able to make good their respiratory losses by photosynthesis. Observations on respiration by phytoplankton organisms indicate that at a sea temperature of $10^{\circ} \mathrm{C}$., they lose some $4 \%$ of their organic matter daily when kept in the dark.

While phytoplankton cells are multiplying there appears to be little tendency 
for them to $\operatorname{sink}$, but as growth slows down owing to lack of nutrients, or light, or other ill-defined causes, the cells tend to lose buoyancy. Besides this, turbulence set up by rough weather, particularly between October and May, when a thermocline is absent, also carries cells to below the compensation level, thereby depleting the growing stock.

These losses may be small compared with those due to the continuous grazing by zooplankton, and, in shallow waters particularly, by filter-feeding bottom-living animals. Otherwise there would be a great accumulation of sinking organisms in the water column below the compensation level.

The rate of multiplication of the standing crop, or rather that portion of it within the photosynthetic zone, is most notably dependent upon the amount of light falling day by day upon the sea, and upon the concentration of nutrients. In some areas the availability of other microconstituents in the water probably affects the rate of multiplication.

The species composition of the standing crop will also influence its growth rate as a whole, since the different species composing the population have different light requirements for optimum growth rate, and these rates vary between different species. Smaller cells tend to grow faster.

The depth of the photosynthetic zone at any moment varies with the intensity of light falling on the sea, and in consequence so does that proportion of the standing crop which is making growth. Although the proportion of the light falling on the sea from month to month is much the same each year, the total quantity during any year varies materially. Thus from I930 to I937, the quantity of daylight falling on this laboratory varied between a daily mean of 307 kilolux hours in 1937 and 4I2 in 1930 (Atkins, I938). Hence in a particular sea-area, changes in the quantity of incident light from year to year are likely to affect plant production.

The concentration of nutrients at any moment in the water in the photosynthetic zone, where it can be used by the plants, is the accumulated excess due to greater replacement than utilization. Replacement takes place by excretion from animals, by regeneration from dissolved organic nitrogen and phosphorus and by nutrients rising into the photosynthetic zone from below due to vertical mixing by turbulence. As far as we know, from experiments with one species only, the concentration of nutrient salts in the English Channel has, for several years, always been less than optimum, and in summer always acts as a powerful brake on the rate of growth.

A mathematical analysis of observations in the Gulf of Maine suggests that the availability of nitrogen and of phosphorus alternate in exerting the greater depressant effect upon growth rate during summer months.

It is helpful to consider the production of vegetation under simplified, hypothetical conditions, where the depth of water is similar to that of the photosynthetic layer. This implies little change in light intensity from season to season, a condition which may be approached in tropical areas. Plant pro- 
duction throughout the year would be maximal if the standing crop kept the concentration of nutrients at such a low level that the daily increase in plant life, and never more, was grazed by zooplankton and the plants utilized the nutrients as quickly as they were being reformed. Thereby the dissolved organic nitrogen and phosphorus would be kept at a maximum, and the rate of replacement of nutrients both by regeneration from it, and by excretion from animals, at a maximum also.

In waters of depths greater than the photosynthetic zone replacements of nutrients, or their immediate precursors, by turbulent diffusion from below, plays an increasingly important part. Zooplankton rise by night to feed in the upper layers, then fall by day and excrete below the zone some of the combined nitrogen and phosphorus which they have collected. There is thus a continuous drain from the upper layers to the water below. Turbulence is the means by which this drain is compensated. Our observation of phosphorus compounds in the water column indicates that this drain downwards becomes pronounced only after the thermocline has formed. Throughout the period of spring diatom maximum, turbulence is sufficient to offset it. In this way turbulence contributes to production, while at the same time reducing production by carrying plant cells downwards.

Present knowledge shows that the production of plant tissue in the sea from day to day depends upon:

(i) The rate of regeneration of nutrients from dissolved organic compounds, particularly within the photosynthetic zone.

(ii) The quantity of nutrients rising by turbulent motion from below.

On (i) and (ii) depends the continuance of growth.

(iii) The population density of zooplankton eating the stock of growing plants.

(iv) The rate of loss of growing cells due to sinking below the zone. This is largely occasioned by turbulence, particularly in winter.

(v) The mean depth of the photosynthetic zone throughout each $24 \mathrm{hr}$. This varies with the quantity of light falling daily on the surface of the sea (Fig. 6) and with the transparency of the water.

On (iii), (iv) and (v) depends the magnitude of the growing stock, or quantity of photosynthesizing phytoplankton.

(vi) The considerable effect of temperature on the respiration rate of the plants, which tends to be offset by its effect upon the rate of regeneration of nutrients and upon the rate of photosynthesis.

(vii) The concentration of nutrients in the water within the photosynthetic zone. These consist of nitrogen in the form of ammonia, nitrate, nitrite and some amino-acids, and of phosphorus in the form of phosphate and probably of some organic phosphorus compounds.

(viii) The concentration of some other constituents of sea water (vide infra). On (v), (vi), (vii) and perhaps (viii) depends the growth rate of the growing stock of plants. 
In nature all these eight factors vary continuously, and most are interdependent upon one another.

Riley's analyses of survey data in several areas have indicated the relative influence of some of these factors and of how their influences change with the seasons. Before this valuable mathematical tool can be used in this area, a reasonably accurate technique of estimating the standing crop of phytoplankton needs to be evolved. However, a consideration of the rather complex and changing picture, which these eight factors presents, leads to a conclusion relevant to this thesis.

In comparing conditions from year to year in the area, small differences in the overall conditions of light, turbulence and temperature are likely to be subordinated to the big differences which may occur in the totals of all forms of combined nitrogen and phosphorus in the water. In the early I920's there was twice as much as in recent years: one would expect that this difference alone doubled the regeneration and supply of nutrients to the growing plants, thereby doubling the production of vegetation except for a short period in the winter.

The possibility that microconstituents, other than nutrients, in the water may affect the growth rate of phytoplankton in nature is indicated by experiments in vitro. These have shown that very minute additions of salts, of iron, of manganese, of other elements, and of several organic compounds, increase the division rate of many species of plankton algae growing in sea water enriched with nutrient salts. Hence it is possible that varying concentration of some of these substances in the sea may affect the production of phytoplankton. Observations by Hart in the South Atlantic actually indicate that, in these nutrient-rich waters, the supply of some constituent derived from land drainage allows the much heavier development of plant life which occurs in some areas than in others. There are numerous observations which show that the multiplication rates of particular species of phytoplankton differ in different sea waters into which they have been introduced, due to microconstituents other than nutrients and iron. It is not known what constituent or constituents may be lacking, nor indeed whether there may be inhibitory organic compounds in the water. Somewhat indefinite evidence of the presence of inhibitors in some waters is provided by experiments by Allen \& Nelson (I9IO) which showed better growth of diatoms after nutrient-enriched waters had been treated with hydrogen peroxide, chlorine or charcoal.

The list of substances which promote growth of marine plants is increasing. Concerning one of the more obvious essentials for growth the following is of interest. The quantity of manganese in an available form in the waters off Plymouth has been shown by experiment to be insufficient for a luxuriant growth of several species of autotrophic flagellates. Samples of water from an area in the Irish Sea, where flagellates are noticeably abundant, contained more than twice the concentration of available manganese found in this area. The inference 
that in nature varying concentrations of this element influence the growth rate of these species seems justified.

In temperate seas, where low concentration of nutrients limits the annual production, a greater rate of multiplication of the plants would correspondingly increase production before and after the duration of the thermocline, and during these periods would allow the plants to keep down the concentration of nutrients to an even lower level. By so doing the dissolved organic nitrogen and phosphorus in the water column are increased, and the rate at which the phosphate and ammonia are released is increased also. In this way, the effect of a greater multiplication rate would be similar to the effect of more intense illumination in early spring and autumn, and would increase the turnover of nitrogen and phosphorus compounds.

\section{The Zooplankton Community}

The wide variety of species in the zooplankton community differ greatly both in size and in their content of water. Moreover, there are considerable differences in the proportion of water in zooplankton from different areas, which are ascribed to differences in quantity of stored lipoids, this again being dependent upon the supply of phytoplankton food. It is, in consequence, desirable to express the quantity of such a mixed community in some one form. The content of dry organic matter is suitable and provides a measure of the value as food for other animals.

The population density of zooplankton organisms, expressed either as number or weight per unit volume, provides a measure of their availability as food for other animals. The quantity of zooplankton below a unit area of the sea is the quantity maintained by the vegetation produced in the water below that unit area. Moreover, the quantity below a square metre of the sea, expressed as weight, allows comparison to be made with observations made elsewhere. Comparable observations have been made, notably off the American Coast and in the Northern Sargasso, where quantitative catches have been dried and ashed, the loss on ignition providing a direct estimate of the organic matter.

The two ecological groups of which the zooplankton is composed-the plant-eating and the wholly predatory organisms-merge into one another; there is no sharp line of distinction between them. From limitations imposed by their size, the smaller organisms are likely to be herbivores. Many of those of medium size are omnivores, and the remainder, forming a small but very varying part of the community, are predominantly carnivores. Many of the latter are of relatively large size-ctenophores, medusae, arrow worms, Tomopteris, and the early planktonic stages of young fish. An exceptional group are the Salps which, although of relatively large size, are predominantly herbivorous. The effect upon the community of these purely predatory organisms is enhanced by the depredations made by pelagic fish, and by 
omnivorous filter-feeding, bottom-living, organisms, more particularly in shallow water.

Almost always the bulk of the zooplankton is composed of the plant-eating group, and of these the bulk consists of juvenile copepods and their nauplii, with a variable, usually small, proportion of the larvae of bottom-living organisms. These latter spend a limited time, between a week and 2 months, forming the temporary plankton, whereas the life span of the copepods, from egg to adult, varies around 6 weeks, with the exception of the brood which lives over the winter months.

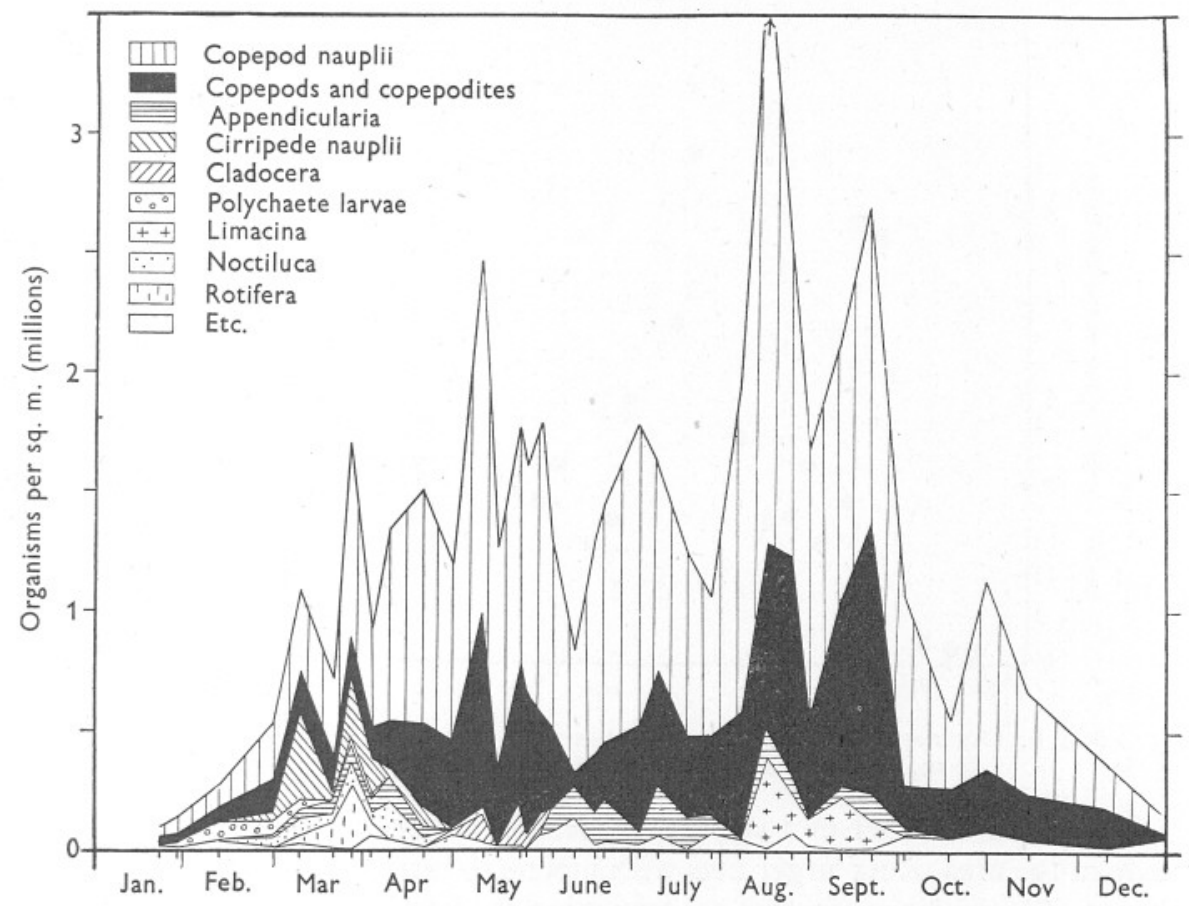

Fig. 7. Number of zooplankton organisms in millions caught in net, below a square metre in the sea off Plymouth, with a depth of $50 \mathrm{~m}$., during 1934. (Harvey, Cooper, Lebour \& Russell, I935.)

Twice a month throughout I934 several vertical hauls were made with a fine silk net at a position 4 miles off-shore from Plymouth, in $50 \mathrm{~m}$. of water. The quantity of water filtered was registered by a meter, and the organisms in an aliquot of the combined catches were counted. The composition of the catch from the water at this position on the various dates is shown in Fig. 7.

The phosphorus content of the animals in a second aliquot of the catch was determined. From their phosphorus content an approximate value of their organic matter can be derived. Analyses of mixed communities, mostly copepods, show them to contain about $83 \%$ of water and $0.2 \%$ of phosphorus. 
Analyses of zooplankton quoted by Fleming give a $\mathrm{C}: \mathrm{N}: \mathrm{P}$ ratio of $40: 7 \cdot 4: \mathrm{I}$ which implies 87 times more dry, ash-free, organic matter than phosphorus.

The values shown on the right of Fig. 8 are derived in this way. After attaining a maximum in early May, the summer population below a square metre fluctuates around a density containing some $2 \mathrm{~g}$. of dry ash-free organic matter, with a significant increase in September. This autumn increase appears to be of frequent occurrence in other areas, and in some to occur before any autumn increase in phytoplankton would be expected, and before the summer population of predatory zooplankton is likely to have died away.

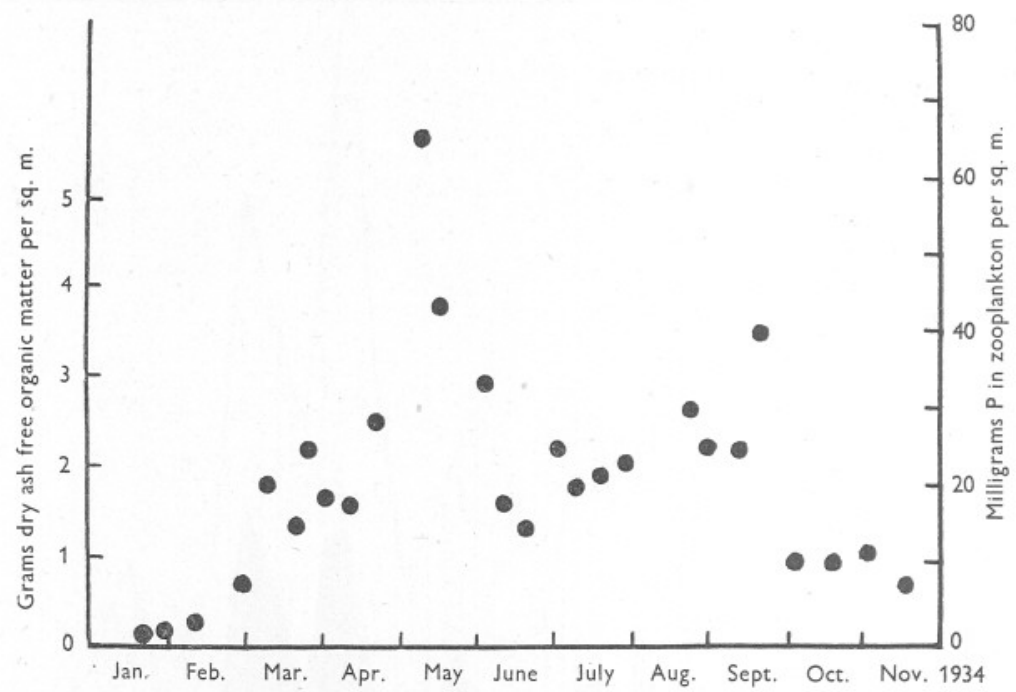

Fig. 8. Organic matter and phosphorus in zooplankton below a square metre, in $50 \mathrm{~m}$. depth, off Plymouth. (Data from Harvey et al. I935.)

During the summer of 1949 , a considerable number of vertical hauls were made in the area using larger nets with meters to register the quantity of water filtered. The primary aim was to determine the patchiness of the distribution of the plankton. So far, it appears that the values shown in Figs. 7 and 8 are a reasonable rough approximation to the mean population density over the area. The catches in 1949 ranged from I to $\mathrm{I} \cdot 7 \mathrm{~g}$. dry weight $(0 \cdot 85-\mathrm{I} \cdot 45 \mathrm{~g}$. organic matter) below a square metre. These are significantly less than found in 1934, when the water contained more nutrient salts in solution at the beginning and at the end of the year.

In June 1947, a series of hauls were made at intervals throughout $24 \mathrm{hr}$. at two positions in the English Channel. These show the variation between one catch and another made in substantially the same body of water, and also indicate the proportion of the biomass which was present as macroplankton caught in the larger net. Vertical hauls between surface and bottom were made with a silk net having a mesh with openings $0.2 \times 0.2 \mathrm{~mm}$., and oblique hauls were made between $35 \mathrm{~m}$. and surface with 
a stramin net having meshes $\mathrm{I} \times \mathrm{I} \mathrm{mm}$. With the latter, the catches varied considerably in quantity, partly due to diurnal migration; hence, for purposes of comparison, the catches made at midnight, when the largest number of organisms have migrated into the upper layers, were chosen.

The composition of the catches shown in wet weight per cubic metre of water filtered is given in Tables I-III.

Table I. Catches made with Silk Net 20 Miles Seaward from Plymouth. Also with 2 M. Stramin Ring Trawl, having i mm. Mesh in Oblique Haul between C. 35 M. AND Surface. 9 and io June I947.

Wet weight in milligrams per cubic metre
of water filtered

Table II. Catches Made with Silk Net and with 2 M. Stramin Ring Trawl at $49^{\circ} 22^{\prime}$ N., $6^{\circ}$ I2' W., BeING 30 Miles South OF THE Scilly ISLES. 28 JUNE I947.

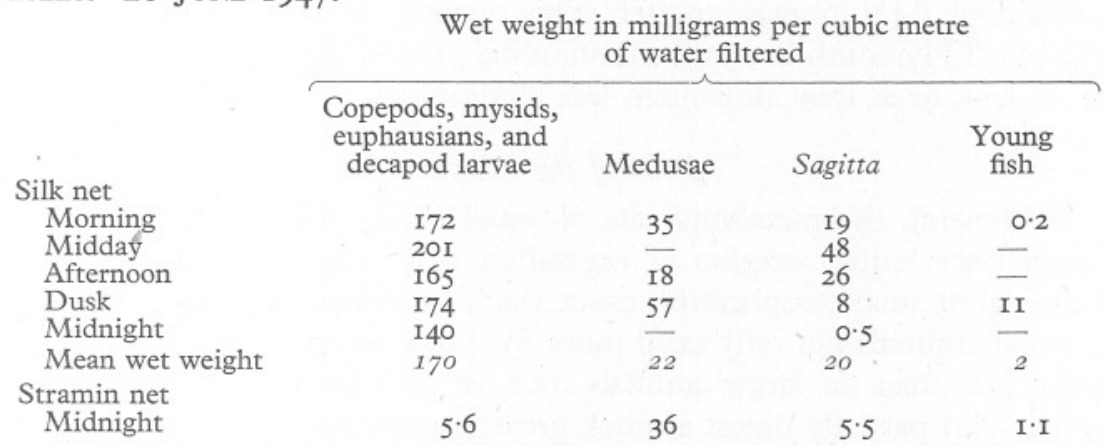

Subsequent analyses of the catches made with the silk net allow mean values of the population density below unit area to be calculated.

Table III. Organic Matter in Zooplankton Below i M. ${ }^{2}$ Caught IN $0.2 \times 0.2 \mathrm{MM}$. Mesh Net (G.). $\begin{array}{ll}20 \text { miles south of Plymouth } & \text { I.6 } \\ 30 \text { miles south of Scilly Isles } & 3 \cdot 5\end{array}$

The estimates made in 1934 and 1949 indicate that the water off Plymouth maintained an average of some $2 \mathrm{~g}$. of organic matter in the form of zooplankton 
below a square metre, after the population peak in April 1934 until October, and a smaller quantity in 1949.

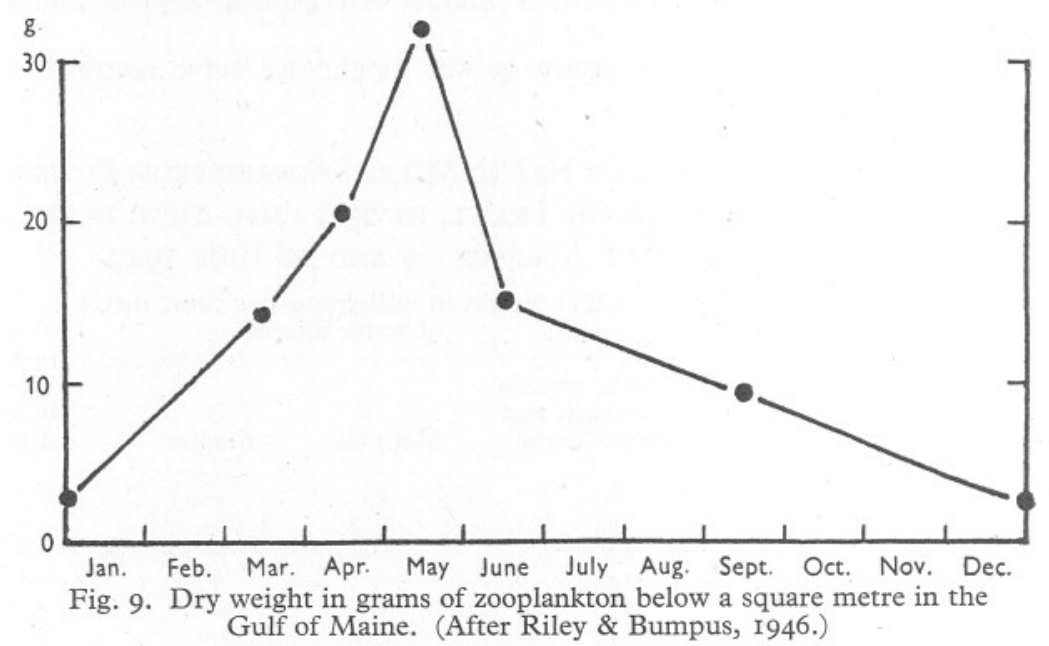

It is of interest to compare these quantities with those found in other areas.

The nutrient-rich waters of the Gulf of Maine, after the peak population in April or May, maintain some I2 g. dry weight of zooplankton, containing about Io g. of organic matter, below a square metre. The waters of the Northern Sargasso between July and September were found to maintain zooplankton containing $\mathrm{I} \cdot 4 \mathrm{~g}$. organic matter. This quantity is rather less than that maintained off Plymouth in I934; the standing crop of phytoplankton also appears to be less, or at least to contain less chlorophyll.

\section{Food of the Zooplankton}

In general, the metabolic rate of small organisms is greater than that of larger ones; equal weights of vegetation will support the life of much less bacterial or small zooplankton tissue than, for instance, lamellibranch tissue.

Small animals not only need more food to make up for their greater metabolic rate than do larger animals, but, in general, weight for weight, they collect and partially digest a much greater quantity. For instance, the larvae of large bivalves, weight for weight, filter very much more water than the adults. They are stated, weight for weight, to digest and oxidize to carbon dioxide a hundred times more food.

In addition to requiring more food to make good their greater respiratory losses, the smaller animals are likely to be more wasteful of the primary vegetable food supply. When a plant is eaten, broken and only partly digested, a quantity of protein and carbohydrate dissolves and escapes into the water. Some of this is used by a sparse flora of bacteria, and possibly, a little by other micro-organisms. The solution is so dilute that the dissolved organic matter 
is not at all readily available. Much of it is surely oxidized by oxygen in the water without being built into the bodies of bacteria. This is entirely lost to the food cycle. For this reason, the feeding habits of organisms in the zooplankton community is of interest.

Many wholly carnivorous species contain much more water than the herbivorous crustaceans-arrow-worms twice as much, ctenophores or medusae ten to twenty times as much-hence, although they may appear bulky, their organic content is usually small compared with that of the omnivores and herbivores forming the remainder of the community. The quantity of the latter which the carnivores succeed in catching and destroying is unknown, but on occasions their depredations appear to be great. During July I949, an area was encountered in the mouth of the Channel, in $6^{\circ} \mathrm{W}$., with a macroplankton fauna very considerable in comparison with that in the water off Plymouth, and consisting largely of medusae and the planktonic worm Tomopteris. Catches with a fine silk net consisted mostly of these worms, while copepods and other crustaceans were almost entirely absent; the quantity of these latter below a square metre was only a small fraction of that in the water off Plymouth. These facts indicate that Tomopteris is a voracious predator, and had succeeded in eating almost all the omnivores and herbivores. Of the other carnivores, the voracity of ctenophores is well known. Bigelow has noted that the smaller plankton animals are locally exterminated in the centres of abundance of Pleurobrachia, which is commonly found packed with copepods or euphausians as well as with larval fish.

The copepods, during their earlier stages, are probably from their very size mostly herbivorous, feeding upon phytoplankton. In their later stages many are omnivorous, eating whatever organisms they are able to catch. Some species, as Temora and Centropages, are notably voracious, and their stomach contents have been seen to consist of other crustaceans and of diatoms. If a Calanus is placed in a dense population of diatoms, it can be seen to extrude green faecal pellets at $20 \mathrm{~min}$. intervals. For greed, voracity and wasteful feeding, many planktonic crustacea are unmatched.

During I933 and 1934, when frequent observations of the population of the phytoplankton large enough to be caught in a net were made, great numbers of such green faecal pellets were found in the water at the time and immediately after the population of the larger diatoms had risen to high values. That this heavy grazing is not limited to the larger plants is indicated by an analysis of observations made in the Gulf of Maine, although it is perhaps the sudden changes in the population density of the larger plants which show the effect of grazing most clearly.

Although the biomass, or quantity of organic matter in the form of zooplankton does not change greatly during the summer, growth is proceeding all the time and providing a daily quota of food for other organisms.

There exist observations on the life history of Calanus finmarchicus which 
allow a rough estimate of the rate of increase in the biomass of individuals of this species during the summer months. It is reasonable to consider this species as rather typical of other copepods, and it is copepods which constitute the bulk of the zooplankton population. A period of some 50 days between egg and sexually mature adult appears usual during the summer, a very much longer period during the winter. The diameter of the egg of Calanus is recorded by Gibbons as $0.172 \mathrm{~mm}$., indicating a wet weight of $0.005 \mathrm{mg}$. The wet weight of sexually mature individuals appearing in the Plymouth waters in summer is recorded as around $0.8 \mathrm{mg}$. Hence in the 50 days there has been a 180 -fold increase in wet weight. In order to proceed with a calculation, an assumption is made that the percentage of dry organic matter in the egg is roughly the same as in the adult. A further assumption is made that the daily percentage increase in weight remains constant during the whole period of 50 days; in actuality there is likely to be a short lag period before logarithmic growth starts and a slowing towards the end of the period. From the equation of geometrical increase, $Q_{t}=Q_{0} \epsilon^{k t}, t$ being 50 days, the daily increase is $10 \%$ of the weight.

There is an independent method of arriving at a rough estimate of this daily percentage increase. During the 50 days between egg and adult, some sixty young are reduced in numbers to two, the two necessary to maintain the population. Meanwhile, the creatures are being eaten steadily. If they are eaten at a rate proportional to their population density, the fall in numbers from sixty to two in 50 days indicates that $7 \%$ are eaten daily. The two estimates (of the daily percentage increase in weight, and of the percentage eaten daily by other animals) are in reasonable agreement.

Concerning the food required by the zooplankton, it is helpful to distinguish between the quantity which is assimilated, and which is either burnt to carbon dioxide in the respiratory processes or is built up into the growing animal, and the quantity which is eaten in excess of that assimilated.

Experimental evidence provides a measure of how much of their body substance is required to be made good in order to compensate for the daily loss by indicated respiration.

Computations, shown in the previous paragraphs, indicate how much is built up daily into the growing animals-from 7 to $10 \%$ of their own weight.

A great variety of animals have been kept in closed containers and the oxygen used by them estimated after a short interval. They appear neither to have been starved nor heavily fed, nor to have been entirely inactive. It seems permissible to assume that the respiration rates found experimentally averaged those of animals growing normally, and, after adjustment for temperature, indicated their average rates when living in the sea.

Experiments with both $C$. finmarchicus and with a mixed community of crustacean plankton indicate that the animals 'burn' $4 \%$ of the carbon in their 
tissues daily, at our summer sea temperature. From descriptions of the experiments the animals had not been starved. From this it is concluded that, of the food which they normally collect and pass through their guts, a quantity of vegetable tissue equal to about $4 \%$ of the animal's tissue is assimilated daily and broken down to carbon dioxide. In addition, a quantity equal to $7-10 \%$ of the animal's tissue is built up into the growing animal. It is unknown whether these lowly animals need the whole range of amino-acids required by mammals, and it is unknown whether phytoplankton protein is deficient in any one or more amino-acids required by the zooplankton. Thus it is possible that the animals need to digest and absorb more vegetable tissue than the sum of the quantities burnt in respiration and built into their own growing bodies.

For simplicity and in order to arrive at a rough calculation it is permissible to treat the whole zooplankton community as herbivores, and the plants as not being deficient in any necessary amino-acid.

It then follows that the population below a square metre of the sea, containing on the average $\mathrm{I} .5 \mathrm{~g}$. of organic matter will require to assimilate daily: $4 \%$ or $0.06 \mathrm{~g}$. of vegetable organic matter to make good respiratory loss; $7-10 \%$ or $0.15 \mathrm{~g}$. to build up into new tissue and provide the daily quota which is used by other animals.

Thus, in this single step in the food chain-vegetable tissue to small quickgrowing animals-about $30 \%$ of the vegetable tissue assimilated is lost as carbon dioxide and $70 \%$ converted to animal tissue.

The zooplankton animals collect and eat more food than they assimilate. Judging by the habits and great voracity of many zooplankton organisms, and by the number of their faecal pellets to be found still coloured green in the sea, they succeed in collecting much more when phytoplankton is abundant.

Since plant life is sparse during periods in the summer, it is of interest to consider how the zooplankton succeed in collecting their ration.

Experiments by different observers with the large planktonic copepod, Calanus finmarchicus, have shown that it can filter very small diatoms from 4 to 5 c.c. of water daily.

This suggests that if the whole summer population were to consist of adult Calanus, the animals below a square metre could filter the very small plants from only about Ioo 1. of water daily. The weight of plant tissue in this quantity of water is negligible.

Experiment has shown that Calanus can catch larger diatoms very much more efficiently than they can filter very small ones. Kept in a suspension of medium-sized diatoms, in an hour each caught the number originally present in 3 c.c. of water. Kept in a suspension of large-sized diatoms each caught in an hour the number originally present in 8 c.c. of water. It is of course possible that in these experiments, where the diatom population was dense compared with that in the sea, the Calanus did not exert their catching power to its fullest extent. 
The results of these experiments suggest that if the summer population below a square metre consisted of late-stage Calanus, it might catch the larger diatoms in $2000-3000$ litres of water daily. Then, for the zooplankton to live entirely on plants, a cubic metre of the sea would need to contain $100 \mathrm{mg}$. of organic matter in plants large enough to be caught in a net.

A population density of plants such as this is of rare occurrence during the summer. We do not know how diatoms are distributed with depth in the waters off Plymouth, but, judging from other areas, they are most concentrated in the upper $30 \mathrm{~m}$. Taking this into consideration, our records indicate that this population density of netable plant tissue occurred only on five occasions out of twenty-eight during the summers of 1934 and 1935 .

During these years the average size of the organisms forming the zooplankton community was only a fraction of that of late-stage Calanus. The smaller animals are, weight for weight, probably more efficient in collecting food than the larger organisms, particularly in filtering the smallest plants.

It appears that the filter-feeding mechanism of the larger zooplankton organisms is not so highly developed that they can obtain much of their food by this method. Indeed experiment with Hemimysis has indicated that it could collect no more very small diatoms than an adult Calanus, which is about one-eighth of its size.

The zooplankton doubtless obtains some food by eating planktonic larvae, eggs, and sperm cells discharged into the water by lamellibranchs and other bottom-living animals. As each one spawns it discharges a considerable fraction of its own weight into the water. However, the daily supply from this source is not likely to contain on an average more than $0.05 \mathrm{~g}$. of organic matter per square metre per day over the summer months, unless the quantity of bottom-living animals has been grossly underestimated.

During the periods of diatom scarcity the copepods' guts are often seen to contain pale brown matter, similar to the once-eaten plants which form most of the organic detritus then in the water. This detritus remains suspended in the water column for a considerable time, kept stirred by tidal streaming and wave action. It seems likely that this detritus, consisting of once-eaten plants, plays a considerable part in the food chain.

\section{Fluctuations in Population Density}

Quite considerable fluctuation may occur from year to year in the average population of zooplankton maintained by the water occupying particular areas of the sea. Observations with the Hardy plankton recorder show this in various areas of the North Sea. It is pertinent to consider likely causes of these fluctuations.

Almost everywhere in the seas there is renewal of the water taking place from time to time, in some places frequently. Waters passing through any area are likely to have different biological histories in their immediate past, and in 
consequence to have different contents of nutrients for plant growth or to have different rates at which these are being regenerated from dissolved organic nitrogen and phosphorus compounds. This in itself will bring about fluctuations from year to year in the plant food for the zooplankton. More zooplankton may be expected to be maintained where there is more phytoplankton over a sufficient period of time for temporary changes in the populations to be ironed out. Comparison of one area with another has long indicated this in a general way, and the more recent quantitative observations by Riley et al. all bear out this belief. Moreover, from observation of the changing populations of diatoms and copepods in a Scottish Loch, where the water is subject to little interchange with other water masses, Dr Marshall (I949) concludes that 'on the whole it does seem that the presence of diatoms increases the production of eggs and nauplii and helps the development of the younger stages' from time to time during the course of the year. Experiment indicates a similar relationship, since by enriching a tank of sea water with nutrient salts Clarke \& Gross (unpublished) have induced a population density of copepods to develop in the water, amounting to several thousands per litre-a remarkable population density when compared with the 50 per litre found in the sea.

Another cause of fluctuations may be due to the copepod population being preyed upon to a different degree from year to year by migratory pelagic fish, or even due to the proportion of carnivorous zooplankton changing materially and for long enough to upset the balance seriously.

Of these two causes of fluctuations in a sea-area, supply of vegetable food appears to predominate. There may well be other circumstances which change from year to year and which play a part in controlling the copepod population, although these are not obvious. A rather remarkable distribution has been observed in the southern North Sea (Rae \& Fraser, I94I). In I920 and I92 I there occurred in January and December a considerable zooplankton population off the coast of East Anglia, and in the winter of I933 off the Dutch coast. This has been attributed to heaping caused by the prevalent wind drift of the upper water layers, and presupposes that during the long winter nights the organisms spend most of the $24 \mathrm{hr}$. near the surface and a lesser period in the compensation current flowing in the deeper layers. These observations, and the inferences to be drawn from them, suggest a mechanism which may play an important part in regulating the distribution of zooplankton in some coastal areas.

When the population densities of two different areas are compared, another factor, and a potent factor, needs consideration. Vertical turbulence, and its effect on the production of plants, is unlikely to be the same. By renewing the nutrient salts in the photosynthetic zone in one area more rapidly than in another, plants are enabled to grow more rapidly so that a similar standing crop of plants can provide a greater daily supply of food for copepods. Yet, in 
spite of this, and of differences in the depth of the photosynthetic zone, and of differences in temperature, the population per unit area of zooplankton does seem to follow roughly that of the phytoplankton in very different sea areas. Our present knowledge points to the average standing crop of plants usually predominating over other causes in controlling the average population density of zooplankton, provided the sea-areas compared with one another are of considerable extent. Within such areas there are liable to be extensive patches where diatoms abound, as in the southern North Sea, in which the zooplankton is less abundant than around the edges of the patches. These patches presumably arise and persist because the intensity of grazing within them is less than in the surrounding waters.

\section{PELAgic Fish}

It is possible to make a rough estimate of the quantity of pelagic fish, mostly herring, in the North Sea, extending over some 170,000 square miles. During the I930's roughly one million tons of herring were landed each year. Of the various year classes caught during any one year, about one-half the quantity is caught during the following year-the annual mortality of adult fish is $50 \%$ from all causes. About three-fifths of this mortality is ascribed to fishing, which is to say that $30 \%$ of all adult fish were caught annually. Hence the quantity of adult fish in the area is some three million tons. To this quantity there needs to be added the smaller fish not large enough to be enmeshed in the herring nets, that is, fish up to and including many 3-year-olds. It is only possible to guess that their weight may be a third or even more than that of the older fish.

If these two assumptions are accepted: (i) that fishing accounts for threefifths of the natural mortality of the older fish, and (ii) that the younger fish, not enmeshed in the nets, aggregate one-third of the larger fish, then the total population amounts to four million tons.

The population would then, if evenly distributed, comprise $\mathrm{I} \cdot 8 \mathrm{~g}$. of dry organic matter below a square metre.

There are no data on which to base a similar estimate of the overall average population density of pelagic fish in the English Channel. All that can be done is to examine a presumption that it is not very different from that in the North Sea. The relative proportion of species is quite different; extensive and dense shoals of pilchard are encountered; great numbers of pilchard eggs are found in the water and further to the westward, in addition, an almost equal number of mackerel eggs. At first sight this suggests a mackerel population similar in over-all density to that of the pilchard. But this is not so, for pilchard eggs hatch out as larvae in a much shorter time than mackerel eggs. The herring fishery in the Channel has never been commensurate, area for area, with that in the North Sea. Although different shoaling habits of the fish could account for this, there is more reason to believe that the overall population density of 
the fish is less in the Channel. The great difference between the two areas is the pilchard population, not present in the North Sea, and exploited in the Channel to only a limited extent on account of a restricted market for this fish. Recently a ship searching for shoals with an echo-sounder has encountered numerous shoals, some quite extensive, half a mile or more across. The fish, when shoaled, are sometimes so dense that they obliterate any 'trace' being recorded from sound reaching the sea bottom and returning to the ship. Furthermore, if a weighted wire is hung from a ship when over a shoal, fish are continually knocking against the wire. Fishing with a ring trawl, having a head rope 260 yards long and encompassing some $4600 \mathrm{~m} .^{2}$ of water, catches of $4800 \mathrm{~kg}$. of pilchard or more have been obtained. These observations suggest that when in shoals, the population density may well amount to about I kg. of fish per square metre, containing $170 \mathrm{~g}$. of organic matter.

This tentative estimate of the density of shoaled fish permits a calculation which suggests that $\mathrm{I} \cdot 8 \mathrm{~g}$. of organic matter per square metre in pelagic fish in the North Sea may not be very different from the overall density in the English Channel. On this assessment the mouth of the Channel, extending to some I0,000 square miles, would contain some $5 \times 10^{10} \mathrm{~g}$. of organic matter as pelagic fish. If these were all pilchard, and all in shoals at a density of I70 g. organic matter below a square metre within the shoal, the shoals together would cover I 8 square miles. This computed I 8 square miles of shoals assumes that all pelagic fish, mackerel, herring and pilchard of all sizes shoal with a similar density and are all present in shoals. They do not do so.

Since many shoals, composed of pilchard only, some extending over half a square mile or more, have been encountered by a single ship during the course of a few months, this total of I8 square miles is not wildly improbable.

The food required by the pelagic fish deserves consideration. Various experiments cited in the literature have shown that fish weighing Io g. or more consume some 21 . of oxygen daily per kilogram of body weight. Most of the experiments have been made at room temperature, which suggests somewhat less consumption at sea temperature. There is no indication that these fish were either starved or heavily fed, so their oxygen consumption under natural conditions, where they are slowly growing, is likely to be similar. The value indicates that $\mathrm{I}-\mathrm{I} \frac{1}{4} \%$ of their tissue is consumed daily, and that a commensurate quantity of their daily intake of food is completely broken down to carbon dioxide. Presumably most of the food eaten in excess of this quantity will be returned to the water either in the form of solids or as partly digested and soluble organic matter, which will serve as food for other organisms and for bacteria. Hence the pelagic fish below a square metre, containing some $\mathrm{I} \cdot 8 \mathrm{~g}$. of organic matter will, on the average, assimilate daily a quantity of organisms containing about $\mathrm{I} \frac{1}{4} \%$ of this amount of organic matter, in order to make good respiratory losses. These fish do not live wholly on zooplankton, although this 
constitutes a large part of their diet. For simplicity in this computation they are assumed to feed on zooplankton alone.

Experiments on the growth of plaice over protracted periods have a bearing upon these rough estimates. In order to maintain their weight, without loss or gain, they needed some $\mathrm{I}_{4}^{1} \%$ of their own weight of animal tissue to be supplied daily as food.

In nature the pelagic fish are growing very slowly indeed, compared with small organisms such as the zooplankton. A herring or mackerel, some few months old and weighing $5 \mathrm{~g}$., will take some 3 years to attain a weight of I00 g., and thereafter increase in weight still more slowly. During the 3-yearperiod it will have lost by respiration some $750 \mathrm{~g}$. of tissue and gained $95 \mathrm{~g}$. by growth.

In this step in the food chain, herbivore to carnivore growing rather slowly to moderate size, only Io or II $\%$ of the assimilated food is converted to carnivore tissue, the other $90 \%$ being respired as carbon dioxide. Whereas in the previous step, phytoplankton to quick-growing herbivore, $70 \%$ of the assimilated food is converted to herbivore tissue, in spite of the more rapid respiratory loss.

These quantities relate to the quantity of food assimilated. In order to increase growth, progressively more food doubtless needs to be eaten than is assimilated. Dawes's (1930, I93I) experiments on the growth of plaice indicate this. A small female fish eating $\mathrm{I} \cdot 9 \%$ of its own weight of mussel flesh daily gained an average of $0.06 \%$ daily; a small male fish eating $2 \frac{1}{2} \%$ of its own weight of mussel flesh daily gained $0.25 \%$ of its own weight daily.

\section{BACTERIA IN SUSPENSION}

No observations have been made of the number of bacteria in the waters of the English Channel; at off-shore positions in other areas there are usually found some Ioo or less per cubic centimetre which are capable of growth on nutrient media. Such plate counts give minimal values of their population density, because the bacteria tend to attach themselves firmly to suspended particles or organisms, and a particle with several attached bacteria would only 'count' as a single organism. Allowing for this, it appears unlikely that the number in off-shore waters exceeds about 1000 per c.c., and that no more than $0.2 \mathrm{~g}$. wet weight occur below a square metre in a water column $70 \mathrm{~m}$. deep. Such a quantity would contain some $0.04 \mathrm{~g}$. of organic matter.

Their numbers in the sea are limited by the great dilution of dissolved organic matter serving as food in the water, probably no more than 5 or Io mg. per litre, about half of which appears to be in forms unsuitable as bacterial food. Their growth is also probably limited by the presence of bacteriostatic substances, whose presence in the sea has lately been confirmed, and by their being ingested by other organisms.

Marine bacteria, at our mean sea temperature, lose by respiration some 
$30 \%$ of their own weight daily, varying from species to species. Their food requirements are great, although their biomass is small. This estimate indicates that no more than some $0.013 \mathrm{~g}$. of dissolved organic matter below a square metre are broken down to carbon dioxide by bacteria daily.

\section{DEMERSAL Fish}

It is unknown what average weight of demersal fish lies below an acre of the English Channel, but it is possible to make a reasoned guess. The North Sea is not strikingly dissimilar in fertility to the English Channel, and for the North Sea extensive data are available.

Approximately half a million tons of demersal fish were landed each year during the I930's. Of fish which were marked and put back in the sea, onethird were caught again within a year. Some lose their marks, others are not reported. This indicates that the total population of marketable demersal fish was about one million tons. Small fish of the same species which either passed through the meshes of the trawls or were thrown back perhaps amounted to an equal weight. In addition there are unmarketable species-particularly those which never grow big. A total population of three to four million tons of demersal fish of all species and sizes is not unlikely. This is equivalent to a mean population density of fish below a square metre containing $\mathrm{I} \frac{1}{2} \mathrm{~g}$. of dry organic matter.

The English Channel is almost certainly less populated than the North Sea. The landings of fish per acre are one-third of the landings from the North Sea, but it is less heavily fished. Statistics show that steam trawlers landed during the I930's rather less demersal fish from the English Channel than from the North Sea per Ioo hr. trawling. ${ }^{1}$

This suggests a mean population density in the English Channel containing $\mathrm{I}-\mathrm{I} \frac{1}{4} \mathrm{~g}$. of organic matter, below a square metre, or some $50 \mathrm{lb}$. wet weight per acre.

Experiment has shown that demersal fish of moderate size completely consume and respire as carbon dioxide about $\mathrm{I} \frac{1}{4} \%$ of their tissues daily, and further that they need to assimilate this quantity of tissue daily to maintain their weight. They feed very largely upon the bottom fauna, and therefore may be expected to assimilate daily a quantity of this containing some $0.015 \mathrm{~g}$. of organic matter, and to eat rather more.

The relatively small consumption by fish compared with that by zooplankton (p. I29) is notable. Most of the planktonic animals reach maturity and die within a few weeks, except the brood which lives through the winter. Fish reach maturity in $\mathrm{I}-7$ years, and a very few individuals may attain a great age; cod and plaice as old as 24 years have been caught.

${ }^{1}$ During the course of an hour's trawling our research vessel sweeps about ro acres of the sea floor and catches on the average rather more than roo lb. wet weight of fish large enough not to escape through the meshes of the net. 


\section{The BotTom Fauna}

A considerable population of animals, live on, and buried in, the sea floor the majority obtaining food by creating a current of water from which plankton and detritus is filtered. The mechanisms for doing this are diverse in kind; many of the organisms lie buried and extrude a tube to the surface through which the water is passed. A smaller number live by passing soil through their guts and, from this, organic detritus and bacteria are utilized. A further small number, notably starfish and gastropods living on the surface, are carnivorous. In addition to these carnivores, demersal fish live on the epiand in-fauna, and constitute perhaps the most effective group of predators. The crabs, prawns and amphipods living on the bottom are thought to be mainly scavengers, most of them making little demand on the living bottom fauna.

The population density of animals which live on, or burrow into, the bottom varies very much from place to place. There are areas where lamellibranchs such as Spisula or, near shore, where the common mussel cover the ground almost touching each other. Here there may be more than a kilogram of moist living tissue on a square metre, containing $150-200 \mathrm{~g}$. or more of dry organic matter. On other areas there are found no more than $25 \mathrm{~g}$. of living tissue containing some $5 \mathrm{~g}$. of organic matter.

As methods of obtaining samples to a depth of about 6 in. have been developed, more and more animal life is being found in bottoms which contain only a rather sparse quantity on or near the surface. Large and aged bivalves are being found, buried, and having thick shells, not readily accessible to starfish and too well protected for their shells to be broken by most fish (N. A. Holme, private communication). The biomass of the fauna occupying sand, shell or gravel bottom appears to be composed largely of aged, slowgrowing, buried individuals of the kind whose daily loss by respiration is slow.

With the exception of a small area near the land, where mud containing organic matter is deposited, there have been only a limited number of quantitative observations where the sea floor has been sampled to a depth of 6 in. or more. Based on these, an average of some roo g. of living tissue in and on a square metre now seems a reasonable estimate. This will contain some $17 \mathrm{~g}$. of organic matter. With the development of more efficient gear, and of under-water photography, a better picture of the biomass of the bottom fauna will be possible.

Of the many kinds of bottom-living animals, except the smallest, only a few are thought to be annual. Those constituting the major part of the biomass may live for several years. There is a worm in our aquarium II years old.

The results of numerous experiments on the respiration rate of various bottom-living animals provide data for a rough assessment of that part of their daily food which is completely consumed to form carbon dioxide. The food which is eaten but not completely consumed by an individual serves as food for other species. That part of it which is built up into living tissue of the 
individual eventually provides food for predators or bacteria. One assumption has again to be made, namely that the animals used for experiment had not been starved, but contained or had recently contained food commensurate with that in their normal natural condition. This assumption would appear valid because the experiments did not aim at obtaining the basal metabolic rate and because the animals in many instances were collected shortly before the experiments.

The experiments, conducted between 16 and $23^{\circ} \mathrm{C}$., show a very much greater respiration rate for small animals (around 200 c.c. of oxygen consumed per kg. of living tissue hourly) than for larger animals (around 80 c.c.). At our mean sea temperature the rates would be probably reduced to about twothirds. Since the biomass of animals, when their population density is around Ioo g. of living tissue per square metre, is mostly composed of larger slowly respiring animals, a mean rate of 80 c.c. oxygen consumed hourly per kilogram of tissue ( $170 \mathrm{~g}$. of organic matter) is indicated. This implies the loss of $1 \frac{1}{4} \%$ of their organic matter daily.

Hence organisms containing $17 \mathrm{~g}$. of organic matter will assimilate $0 \cdot 2 \mathrm{I} \mathrm{g}$. daily for their maintenance. There is no evidence that the population waxes and wanes with the seasons; however, the food to maintain the population will vary with the temperature of the water, although many of the organisms are likely to adapt their metabolism to slowly changing temperature.

It is remarkable that the population density of filter-feeding organisms on the sea floor should vary so greatly, often over extensive areas adjacent to each other, between which there is no reason to suppose the filter-feeders' food supply differs to any material extent.

Survival, particularly of the young, from predators, must play a considerable part in regulating the population density. For instance, an area in Plymouth Sound was heavily populated with mussels $4-5 \mathrm{~cm}$. long in 1947, when Asterias, which had either settled there as larvae or had moved in from an adjacent area, decimated the population. However, it seems very improbable that the balance of life between carnivores and filter-feeding organisms can wholly account for the very different populations of the latter, except in isolated areas of limited geographical extent. Another instance of rapid change in bottom fauna in this vicinity does not allow any such simple explanation. An area of several square miles in Start Bay was very thickly populated with Spisula; within a period of some 2 months a heavy mortality took place, most of the Spisula shells sampled being then either empty or containing a dead organism; this catastrophic mortality had no obvious cause.

The nature of the sea floor has a marked influence not only on the species composition of the fauna, but also upon its density in terms of biomass. The former is readily understandable, the latter less so, for among the thousands of species of filter-feeding bottom-living organism, there must be many suited to life on or in all kinds of soils, with the exception of shifting sand which would 
dislodge or bury their young. It is perhaps pertinent that under-water photography has shown ripple marks on sand at quite considerable depths, which suggests that the effect of gales may extend to depths hitherto unexpected.

The kind of sea bottom undoubtedly affects the settlement of larvae of particular species, and their metamorphosis. By partially filling bottles with soil from different sea bottoms and suspending them in the sea, Thorson concluded that planktonic larvae, which metamorphosed and settled, were able to choose their substratum. From experiment with the planktonic larvae of the worm Ophelia, Wilson showed that for metamorphosis and growth a clean sand was necessary with rounded grains about three times their own size. For these larvae, the size and shape of the interstices between the sand grains appears to render the bottom suitable or otherwise. Further investigation is now showing the influence of yet another factor. A species of the worm Protodrilus inhabits an area of shell-gravel. Remarkable experiments by Jägersten indicate that metamorphosis of these planktonic larvae is caused by a chemical substance which slowly dissolves out of this shell gravel, to which its distribution is limited. Experiment has also shown that low concentrations of copper promote the settlement and metamorphosis of ascidian larvae; these concentrations, though low, being several times greater than that usually occurring in sea water. The settlement, metamorphosis and subsequent growth of oyster larvae on different surfaces has been the subject of much investigation. This has led to the observation by Cole \& Knight-Jones that they settle in greater numbers on surfaces where oysters have already settled than on comparable surfaces where settlement has not already taken place.

The distribution of the bottom fauna in soil communities, resulting in part at least from the exercise of choice by the larvae while members of the temporary plankton, causes another factor to affect the density of settlement or resettlement on the sea floor. Currents or drift of the water, which tend to change from time to time, may carry the larvae away from their suitable substratum. There is evidence of this happening in the Dogger Bank area.

In spite of these limitations to spreading and replacement of the population, it is still remarkable that the population density should vary so greatly.

\section{BACTERIA IN THE SEA FLOOR}

Several estimates have been made of the number of bacteria in marine muds containing organic detritus, in which they are likely to be more numerous than in clean open-sea deposits. Their numbers fall off rapidly below the upper layer of mud.

In the limited area of mud lying off Plymouth, investigated by Mare (1942), counts by dilution and plating indicate some $\frac{1}{2} \mathrm{~g}$. wet weight of bacteria per square metre, containing about $\mathrm{O} . \mathrm{I}$ g. of organic matter. Owing to their rapid respiration, bacteria lose some $30 \%$ of their substance daily at sea temperature, the rate varying with different species. Hence the complete combustion of $0 \cdot 03 \mathrm{~g}$. of organic matter daily per square metre due to bacterial activities is indicated. 


\section{ON the Quantity of Organisms Present, AND Their DaILY FoOD REQUIREMENTS}

The mean quantity of organisms present throughout the year, per unit area over a considerable expanse of sea in the Plymouth sea-area, is set out in Table IV. Each quantity is deduced from the foregoing conclusions.

These rough estimates point to the pelagic organisms requiring vegetable food from which to assimilate some $0.23 \mathrm{~g}$. of organic matter daily. There results from this intake zooplankton containing $0.15 \mathrm{~g}$. of organic matter, a portion of which nourishes the pelagic fish, the remainder being eventually eaten by the bottom fauna.

Table IV. Mean Quantity throughout the Year of Plants and Animals Below Unit Area, the Average Depth being $70 \mathrm{M}$.

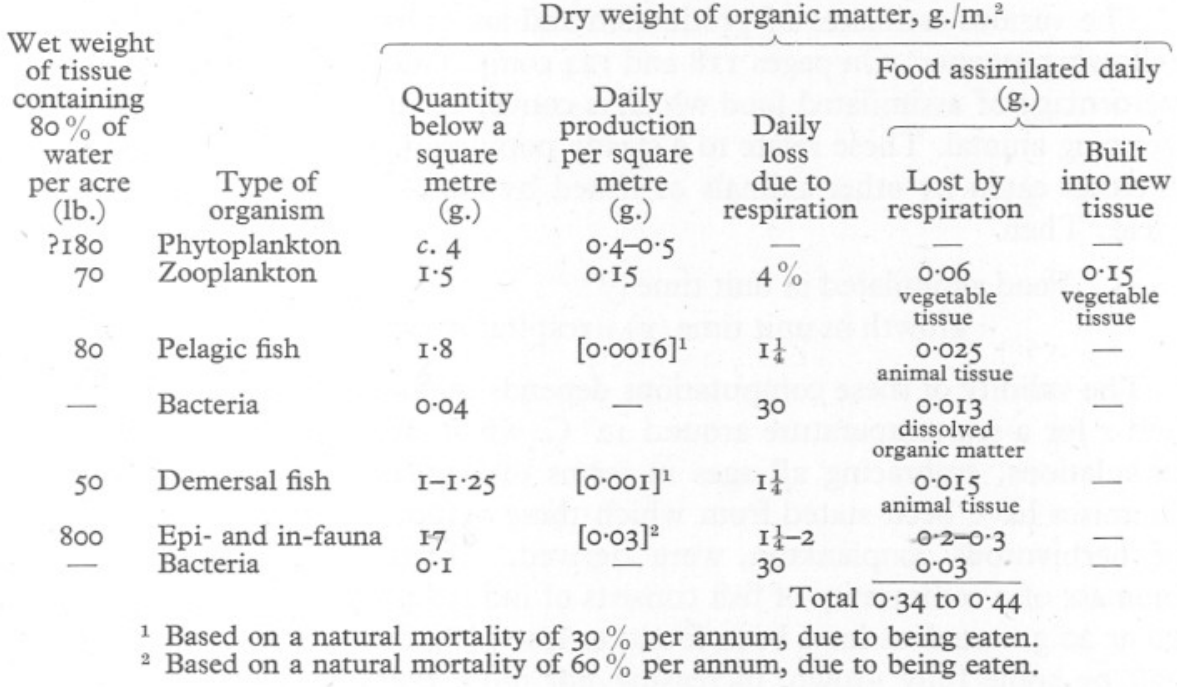

Thus half of the deduced daily production of vegetable tissue appears to be assimilated by plant-eating organisms in the water column, leaving the other half, together with $0.12 \mathrm{~g}$. of zooplankton organic matter, to maintain the bottom fauna, including the demersal fish feeding upon it.

In this table the zooplankton, assessed as containing $\mathrm{I} \cdot 5 \mathrm{~g}$. of organic matter per square metre on the average throughout the whole year, has been treated as entirely herbivorous. This it never is, and on rare occasions there may even be a considerable proportion of carnivores for short durations of time. On account of this alone, the relative proportion of plant to animal tissue available for the bottom fauna will vary. Furthermore, the ten per cent daily production is taken as persisting throughout the whole year, whereas it slows in winter. In consequence the estimate is more likely to be high than low.

Nevertheless, these observed and computed quantities shown in Table IV 
indicate the dominant part played by zooplankton as consumers of vegetation and providers of food for animals higher in the food chain. They indicate that the production of zooplankton (0.15 g. daily or $2200 \mathrm{lb}$. wet weight per acre yearly) exceeds the production of all other animals.

The total daily loss by respiration of the whole animal community $(0.34-0.44 \mathrm{~g}$. of organic matter) is slightly less than the deduced daily production of organic matter. No significance is attributed to the total of the crudely estimated animal and bacterial requirements being rather less than the even more crudely estimated production of vegetable organic matter. Yet one might expect some loss of organic matter due to oxidation taking place in the sea without the agency of bacteria or other organisms. Experiments by Keys, Christensen \& Krogh (1935) on the oxygen consumption by bacteria in stored sea water lends credence to an expectation of somenon-vital oxidation in the sea.

The various estimates of production and losses have been arrived at in the following manner. On pages II 8 and I24 computations have been made of the percentage of assimilated food which is converted into additional tissue in the growing animal. These relate to a steady population where the daily accretion is either eaten by other animals or fished by man-where growth equals the yield. Then

$$
\begin{aligned}
& \text { Food assimilated in unit time }(f) \\
& \quad=\text { growth in unit time }(g)+\text { respiratory loss in unit time }(r) .
\end{aligned}
$$

The validity of these computations depends upon having chosen values of $g$ and $r$ for a sea temperature around $12^{\circ} \mathrm{C}$. which are representative of whole populations, embracing all ages in terms of biomass, not of numbers. The premises have been stated from which these values, relating to a community of herbivorous zooplankton, were derived. Much the greater part of the biomass of a community of fish consists of individuals of moderate size-over IO or $20 \mathrm{~g}$.- - such as have been found to lose $\mathrm{I} \frac{1}{4} \%$ daily by respiration. There will be some fully grown, increasing not more than about $20 \%$ by weight annually ( $2-3 \%$ in linear dimensions) and respiring rather less rapidly. There will also be a small proportion by weight of quite small fish respiring more rapidly. For the whole community a loss by respiration of $\mathrm{I} \cdot 25-\mathrm{I} \cdot 5 \%$ daily appears a reasonable mean value. The growth rate, which, under the circumstances postulated, equals the rate of yield and the rate of mortality, is thought to lie in the region of 30-50\% per annum for the major part of the biomass, much more for the small portion of it composed of quite small fish and less for the older larger fish. This indicates a growth rate of $0.08-0.14 \%$ per day. Observations of the bottom fauna indicate that most of the biomass is composed of well-grown organisms, many of considerable size. Even in the mud investigated by Mare, only I \% of the biomass consisted of micro- and meiobenthos. Well-grown bivalves and worms have been found to lose about $\mathrm{I}-\mathrm{I} \cdot 25 \%$ daily in respiration, quite small organisms very much more. 
If, as a rough approximation, about a quarter or a third by weight of the bottom fauna is assumed to lose $4 \%$ daily on an average, and the remainder $\mathrm{I} \frac{1}{4} \%$, the whole community loses $2 \%$ daily. Concerning the rate of yield or mortality of this community, most of the biomass consists of long-lived animals feeding on vegetable and zooplankton detritus, many having attained an age of several years. A mortality rate of $60 \%$ of the biomass per annum seems a not unreasonable conjecture.

On these premises Table $\mathrm{V}$ is also constructed. It suggests that every Ioo g. of vegetable tissue assimilated may yield:

$70 \mathrm{~g}$. of herbivorous short-lived zooplankton.

II g. of herbivorous well-grown long-lived bivalves or worms.

4-7 g. (6-10\% of $70 \mathrm{~g}$.) of pelagic fish feeding on herbivorous zooplankton.

I g. (6-10\% of II g.) of demersal fish feeding on well-grown bivalves.

$0.3 \mathrm{~g}$. of carnivore feeding on carnivore, as fish on fish; or more if both are small and short lived.

It is implied that all the animal food eaten by carnivores is assimilated.

Table V. Balance Sheet of Animal Protoplasm

\begin{tabular}{|c|c|c|c|c|}
\hline & $\begin{array}{c}\text { Percentage loss } \\
\text { of biomass } \\
\text { per annum } \\
\text { 'Annual } \\
\text { Mortality' }\end{array}$ & $\begin{array}{l}\text { Percentage } \\
\text { increase } \\
\text { daily by } \\
\text { weight } \\
(g)\end{array}$ & $\begin{array}{l}\text { Percentage } \\
\text { loss } \\
\text { daily by } \\
\text { respiration } \\
(r)\end{array}$ & $\begin{array}{l}\text { Percentage } \\
\text { of food } \\
\text { assimilated, } \\
\text { which is } \\
\text { built into } \\
\text { new tissue } \\
\left(\frac{\text { IOog }}{g+r}\right)\end{array}$ \\
\hline $\begin{array}{l}\text { Zooplankton herbivores } \\
\text { Fish, community of all } \\
\text { ages }\end{array}$ & $\left\{\begin{array}{l}30 \\
50\end{array}\right.$ & $\begin{array}{l}\text { I0 } \\
\left\{\begin{array}{l}0.08 \\
0.14\end{array}\right.\end{array}$ & $\left\{\begin{array}{l}4 \\
I \cdot 25^{-I} \cdot 5\end{array}\right.$ & $\left\{\begin{array}{l}70 \\
\left\{\begin{array}{l}5-6 \\
8 \frac{1}{2}-10\end{array}\right.\end{array}\right.$ \\
\hline $\begin{array}{l}\text { Bottom fauna, most of the } \\
\text { biomass being well-grown } \\
\text { individuals }\end{array}$ & 60 & 0.16 & 2 & II \\
\hline $\begin{array}{l}\text { Full-grown fish, bivalves } \\
\text { or worms, increasing in } \\
\text { tissue weight not more } \\
\text { than } 20 \% \text { per annum }\end{array}$ & - & $<0.05$ & $I-I \cdot 25$ & $<5$ \\
\hline
\end{tabular}

Although the premises on which these computations are founded are not sufficiently exact for definite quantitative conclusions to be drawn, they provide or expand a series of implications, most of which are self-evident without any such quantitative reasoning. Thus the yield, derived from the same quantity of primary vegetable food, will be still further reduced for every step in the food chain, if the food supply is inadequate. The average age, and the size, of individuals constituting an ecological group will have a profound effect upon this yield: if the respiration rate is doubled or the growth rate halved, the effect upon this yield will be the same, hence a higher sea temperature may be partially offset by an increased growth rate. The yield of pelagic 
fish feeding on herbivorous plankton will be greater than that of demersal fish feeding on slowly growing bivalves, provided that both can collect a sufficiency throughout the whole year.

In addition to the losses which occur for every step in the food chain, there is a deterioration of food every time an organism is eaten or mutilated, due to organic matter passing into solution and becoming useless as food except for bacteria and possibly for some protozoa.

The estimates shown in Tables IV and V, and computations based on them, can only be accepted as pointers and not as conclusions, only as a first attempt to envisage the changing life in the sea as a whole and on a roughly quantitative basis. The estimates themselves are rude, but they are not notional, being founded on observation and experiment.

These estimates envisage the sea maintaining an average of $1000 \mathrm{lb}$. of animal tissue per acre. Is this quantity surprisingly great? The food chain leading up to many of the animals is long and this is not conducive to great fertility. On the other hand, it appears to be animals larger than bacteria and protozoa which convert most of the plants and each other into carbon dioxide. This constitutes a great difference between life in the sea and on land, where a proportion of the vegetation nourishes a considerable soil fauna of bacteria and protozoa. On the other hand, rich pastures may also maintain, out of sight, as much as $600 \mathrm{lb}$. per acre of worms and much insect life (Evans, 1948).

With a better 'balance of life' there is reason to suppose that the sea could maintain and yield an almost phenomenal quantity of animals compared with cattle on land. The Chinese have evolved a system where shallow sea-areas are banked off and filled with water from which predatory animals have been screened out. After the growth of algae has started, the 'ponds' are stocked with the fry of a quick-growing herbivorous fish. In the Phillipines, as described by Frey (1947), and also on the coast of India, this system is yielding as much as $5000-7000 \mathrm{lb}$. of fish per acre annually. At intervals of not more than 2 years, the ponds are drained and the mud bottoms allowed to bake in the sun; also, in India, they are ploughed. This treatment presumably affects the interchange of nutrient salts between soil and water, allowing more to pass into solution and preserve the pond's fertility.

\section{Evidence of Changing Fertility}

The term 'fertility' of a sea-area, in its wide sense, implies the annual production of plants and the average quantity of animals maintained in it throughout the seasons. This quantity includes the bottom-living and migratory animals; neither of these allow quantitative sampling with any exactitude. It also includes the planktonic life in the water mass which does not usually remain in the area for any length of time, and is always subject to being replaced by another of very different biological history and potentialities. 
The term 'fertility' comprises three concepts:

(i) The production of plants rather than their population density. Since, in most areas, production is directly dependent upon the supply of nutrients throughout a part of the year, the potentiality of the water to supply these nutrients is an almost direct measure of fluctuation in plant production from year to year. This potentiality to supply depends upon physical factors-as turbulence and temperature, changing with the seasons and varying from area to area-and the water's content of total combined nitrogen and phosphorus. Hence the concentration of one or other of these in the water provides a measure of the potential fertility of the water mass with respect to its production of plants.

(ii) The population of animal plankton living on the plants, changing with the seasons and providing food for the carnivorous plankton. This whole population of animals and plants moves in and out of a sea-area with the water masses. Short-term fluctuations in the phytoplankton and in the herbivorous zooplankton assuredly affect the early survival of most other animals, for which they are the only food during larval life. The quantity of planktonic life in the water also affects, or often affects, the movements of the migrating pelagic fish.

(iii) The population of longer lived animals which, once established, are able to withstand rather long periods of starvation. Where the bottom fauna is abundant it is notable that the greater proportion by weight is composed of relatively large and aged animals, and this also holds for the fish. This established population, which appears to comprise more than half the weight of living organisms, will be least subject to immediate changes from fluctuations in food supply due to changing water masses in the area. Their early stages, however, and the chances of this population maintaining itself by renewal, is very dependent upon the supply of planktonic food. The larvae need a population of food suited to their particular need, a population of organisms sufficiently dense for the larvae to be able to catch enough, a population present throughout the whole early life of the larvae. It is during their larval life that their respiration rate is greatest and they have not sufficient food reserves to live through an interval of starvation.

From general observations in the Plymouth area there is little doubt that the quantity of both pelagic and bottom-living organisms has decreased during the past 30 years. This opinion is not founded on measurement, but it is reinforced by the results of sampling and measuring particular populations and conditions.

Since 1924 comparable hauls have been made at weekly intervals with a stramin net, having meshes with openings around $\mathrm{I} \times \mathrm{I} \mathrm{mm}$., each haul filtering roughly $4000 \mathrm{~m}^{3}$ of water. During I 924,1926 and I929, consistently heavy catches were made, containing considerable quantities of late-stage copepods and euphausians. During 1925 and 1927 the catches were much less: during 
subsequent years, particularly recently, catches have been very sparse indeed. It was soon observed by Russell that a relation existed between the size of the catches and the phosphate in the water at the beginning of each year.

The numbers of young fish in the catches were recorded. Of these, the number of clupeid fish varied in a very irregular manner in the daytime, and many more were caught at night (Russell, I930). Hardy records catches of $2448,27,7$, and $34 \mathrm{I}$ young herring in comparable vertical hauls, at intervals of a few hours, at substantially the same position in the North Sea. The numbers of young demersal fish, caught in each haul in this area, present a more regular picture.

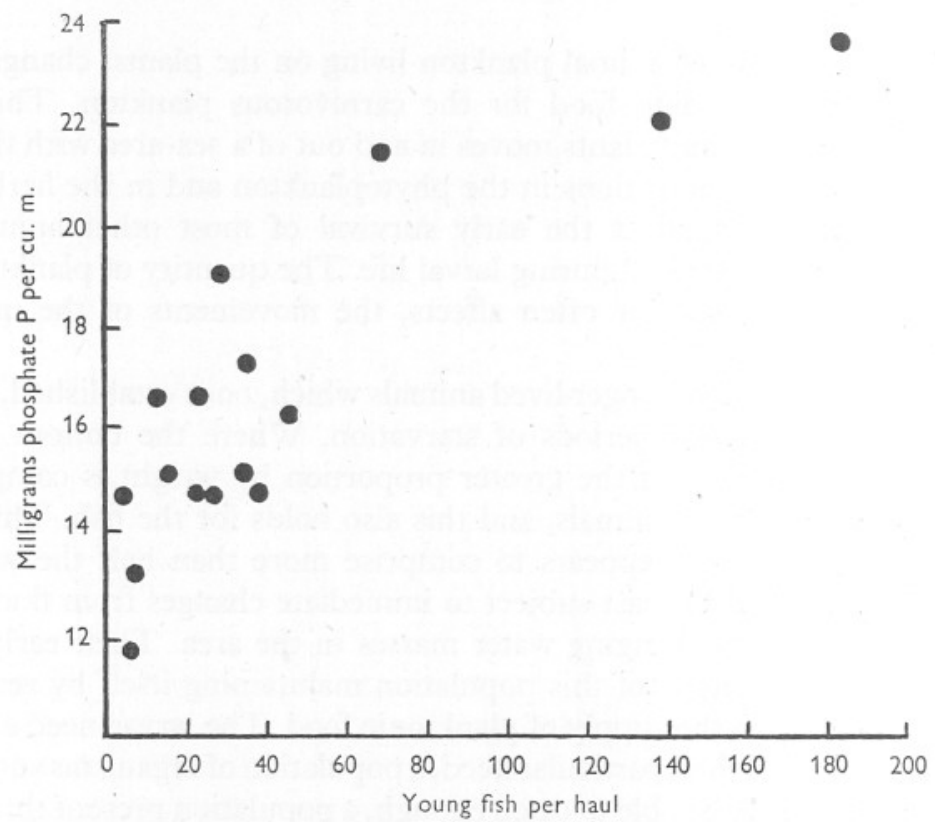

Fig. Io. Relation between the number of young fish caught per haul and the phosphate in the water occupying the area during the previous winter.

The average number caught between June and October are plotted against the concentration of phosphate in the water at the beginning of each year in Fig. IO. These numbers relate to fish spawned in summer, after the spring outburst of phytoplankton, and after the peak population of planktonic crustaceans which immediately follows it. These young fish lived their early life during a season when food was not at its greatest seasonal abundance.

At about the time when these fish larvae have absorbed their yolk sac, or very shortly after, they need to catch small crustacean or other larvae. This is a most critical period of their lives, when great mortality occurs. Observations by Rollefsen show that the food organisms need to be below a certain size. If unable to pass down a fish's gullet with an effective diameter of 0.2- 
$0.3 \mathrm{~mm}$. they choke the fish. If organisms of small enough size are not sufficiently numerous, an increasingly large proportion of the larval or postlarval fish fail in their attempts to catch food during the critical period, and so perish. A major cause of good or bad survival years for young fish would appear to be the population density of zooplankton organisms of the right size at the right time.

There are three steps in the food chain between the young fish which have survived the post-larval stage and the quantity of plant nutrients. Furthermore, the quantity of nutrients in winter may sometimes bear no relation to the production of plants in the area during summer, on account of a different water-mass with very different potential fertility having meanwhile entered the area. In spite of this, the highest winter concentrations of phosphate are seen to have marched with the most considerable survival of post-larval fish during the following summer, and the least winter concentrations of phosphate with the least survival.

Another relation appeared during the course of these observations. The rich plankton populations found in the nineteen-twenties contained Sagitta elegans in considerable numbers, whereas in the sparse populations this species was replaced by $S$. setosa. During a cruise in 1935 there appeared to be a rather sharp line of demarcation between plankton-rich water containing $S$. elegans and plankton-poor water containing $S$. setosa. Thus it emerged that, like the winter concentration of nutrient salts, the presence of some plankton species marched with the quantity of the whole planktonic population.

There are observations made during 3 years which allow a comparison of the quantity of the larger phytoplankton organisms in the water. Frequent vertical hauls with a net of $0.05 \times 0.04 \mathrm{~mm}$. mesh, containing a meter, were made at the same position. The results expressed in terms of plant pigments per cubic metre (Harvey, Cooper, Lebour \& Russell, I935, p. 4I9, and fig. I2, p. 424) indicate a lesser population of these larger plants in 1949 than in 1934, and lesser in I934 than in I933. The quantity of phosphate in solution in the water during the previous winters varied in the same way ( $\mathrm{I}_{3}, \mathrm{I}_{5}$ and $\mathrm{I} 6 \mathrm{mg}$. P per cubic metre respectively) although the differences were not great. The average number of post-larval fish, exclusive of clupeids, caught in $4000 \mathrm{~m} .^{3}$ of water between June and October also varied in the same way (IO, I6 and 23 fish per haul). Standing alone, this close relation between winter nutrients, larger plants, and summer-spawned young fish, would mean little, since it only embraces 3 years.

Observations of the population of smaller zooplankton (copepods and copepodites) extend over 2 years only, I934 and I939. Neither the quantity of zooplankton, the number of young fish in summer nor the winter phosphate were notably dissimilar. 


\section{BIBLIOGRAPHY}

Armstrong, F. A. J. \& Harvey, H. W., I950. The cycle of phosphorus in the waters of the English Channel. Fourn. Mar. Biol. Assoc., Vol. 29, pp.

Atkins, W. R. G., I928. Seasonal variations in the phosphate and silicate content of sea water during I926 and 1927 in relation to the phytoplankton crop. Fourn. Mar. Biol. Assoc., Vol. 15, pp. I91-205.

- 1938 . Photoelectric measurements of the seasonal variations in daylight around 0.4I $\mu$ from I930 to 1937. Proc. Roy. Soc. London, Vol. I65, pp. 453-65.

Allen, E. J. \& Nelson, E. W., I910. Artificial culture of marine plankton organisms. Quart. Fourn. Micr. Sci., Vol. 60, pp. 36I-43I.

Bogorov, B. G., 1934. Seasonal changes in the biomass of Calanus finmarchicus in the Plymouth Area. Fourn. Mar. Biol. Assoc., Vol. I9, pp. 585-6I2.

BRAARUD, T., I945. Experimental studies on marine plankton Diatoms. Avh. norske VidenskAkad., Oslo, Mat.-Naturv. Klasse, 1944, No. ro.

Brandt, K., I899. Chemischen Zusammensetzung des Planktons. Wiss. Meeres. Kiel, No. 3 .

Cole, H. \& Knight Jones, E., I949. The settling behaviour of larvae of the European Oyster. Fish. Invest., Ser. 2, Vol. 17, No. 3.

Cooper, L. H. N., 1933. Chemical constituents of biological importance in the English Channel. Fourn. Mar. Biol. Assoc., Vol. 18, pp. 677-753.

Copenhagen, W. J. \& L. D., I949. Variations in phytoplankton of Table Bay. Trans. Roy. Soc. S. Africa, Vol. 32, pp. II3-23.

Dawes, B., 1930. Growth and maintenance of the plaice. Fourn. Mar. Biol. Assoc., Vol. 17, pp. 103-74.

- I93I. Growth and maintenance of the plaice. Fourn. Mar. Biol. Assoc., Vol. I7, pp. $877-948$.

DutTon, H. \& MANNING, W., I94I. Evidence for carotenoid-sensitized photosynthesis in the diatom Nitzschia closterium. Amer. Fourn. Bot., Vol. 28, pp. 516-26. See also Strain \& Manning, I942. Fourn. Amer. Chem. Soc., Vol. 64, p. I235.

ENY, D., I949. Amino-acids in Chlorella cells. Fourn. Bact., Vol. 58, p. 269.

Evans, A. C., I948. Studies on the relationship between earthworms and soil fertility. Ann. Applied Biol., Vol. 35, pp. I-I3.

Frey, D., I947. The pond fisheries of the Philippines. Fourn. Mar. Res., Vol. 6, pp. $247-58$.

GaARDER, T. \& Gran, H. H., 1927. Production of plankton in Oslo Fiord. Rapp. et Proc. Verb. Cons. int. Explor. Mer, Vol. 42, pp. I-48.

GessNer, F., I943. Die assimilatorische Leistung des Phytoplanktons auf seinen Chlorophyllgehalt. Zeit. für. Bot., Bd. 38, pp. 4I4-24.

GibBons, S. G., I933. A study of the biology of Calanus finmarchicus in the northwestern North Sea. Fish. Scot. Sci. Invest. 1933, No. I.

Glaser, O. \& Anslow, G., I949. Copper and ascidian metamorphosis. Fourn. Exp. Zool., Vol. III, pp. II7-40.

Grave, C. \& Nicoll, P., I940. Studies of larval life and metamorphosis in Ascidia nigra. Pap. Tortugas Lab., Vol. 32, p. I.

Grave, C., I94I. Studies in the metamorphosis of Ascidian larvae. Biol. Bull. Woods Hole, Vol. 8r, p. 286.

Gross, F., 1937. The life-history of some marine plankton diatoms. Phil. Trans. Roy. Soc. London B, Vol. 228, pp. I-47.

HaRvey, H. W., 1947. Manganese and the growth of phytoplankton. Fourn. Mar. Biol. Assoc., Vol. 26, pp. 562-79. 
Harvey, H. W., 1949. On manganese in sea and fresh waters. Fourn. Mar. Biol. Assoc., Vol. 28, pp. I55-64.

Harvey, H. W., Cooper, L. H. N., Lebour, M. V. \& Russell, F. S., I935. Plankton production and its control. Fourn. Mar. Biol. Assoc., Vol. 20, pp. 407-42.

JÄGERSTEN, G., I940. Die Abhangigkeit der Metamorphose vom Substrat des Biotops bei Protodrilus. Arkiv. Zool., Bd. 32, A, No. 17.

Ketchum, B. H. \& RedField, A. C., I949. Some chemical and physical characteristics of algae grown in mass cultures. Fourn. Cell. Comp. Physiol., Vol. 33, pp. 281-300.

Keys, A., Christensen, E. \& Krogh, A., I935. Organic metabolism in sea water. fourn. Mar. Biol. Assoc., Vol. 20, pp. 181-96.

MARE, M. F., I942. A study of a marine benthic community with special reference to the micro-organisms. Fourn. Mar. Biol. Assoc., Vol. 25, pp. 517-54.

Marshall, S. M., 1949. On the biology of small copepods in Loch Striven. Fourn. Mar. Biol. Assoc., Vol. 28, pp. 45-II2.

Mazur, A. \& Clarke, H., I938. Amino-acids of certain marine algae. Fourn. Biol. Chem., Vol. 123, pp. 729-40.

Ministry of Agriculture AND Fisheries, 1934-38. Sea Fisheries Statistical Tables.

RAe, K. M. \& Fraser, J. H., I94I. The Copepoda of the southern North Sea. Hull Bull. Mar. Ecol., Vol. I, No. 4, pp. I7I-238.

RILEy, G. A., I94I. Plankton studies. IV. Georges Bank. Bull. Bing. Oceanogr. Coll., Vol. 7, (4), pp. I-73.

- - 1946. Factors controlling phytoplankton populations on Georges Bank. Fourn. Mar. Res., Vol. 6, pp. 54-73.

- - 1947. Seasonal fluctuations of the phytoplankton population in New England coastal waters. Fourn. Mar. Res., Vol. 6, pp. II4-25.

Riley, G. A. \& Bumpus, D. F., I946. Phytoplankton-zooplankton relationships on Georges Bank. Fourn. Mar. Res., Vol. 6, pp. 33-47.

RILEY, G. A. \& GoRGY, S., I948. Quantitative studies of summer plankton populations of the western North Atlantic. Fourn. Mar. Res., Vol. 7, pp. I00-2I.

Riley, G. A., Stommel, H. \& Bumpus, D. F., I949. Quantitative ecology of the plankton of the western North Atlantic. Bull. Bing. Oceanogr. Coll., Vol. I2, No. 3, pp. I-I69.

RUSSELL, F. S., I930. The vertical distribution of marine macroplankton. IX. The distribution of the pelagic young of teleostean fishes in the daytime in the Plymouth area. Fourn. Mar. Biol. Assoc., Vol. 16, pp. 639-70.

- I935. The seasonal abundance and distribution of the pelagic young of Teleostean fishes caught in the ring trawl in offshore waters of the Plymouth area. Fourn. Mar. Biol. Assoc., Vol. 20, pp. 147-80.

- - 1936. Observations on the distribution of plankton animal indicators, made on Col. E. T. Peel's yacht St George in the mouth of the English Channel, July 1935. Fourn. Mar. Biol. Assoc., Vol. 20, pp. 507-22.

Thorson, G., I946. Reproduction and larval development of Danish marine bottom invertebrates, with special reference to the planktonic larvae in the Sound (Øresund). Medd. Komm. Danmarks Fisk. Havund, Ser. Plankton, Bd. 4, No. I, $523 \mathrm{pp}$.

Wirson, D. P., I948. The larval development of Ophelia bicornis Savigny. Fourn. Mar. Biol. Assoc., Vol. 27, pp. 540-53.

ZEUTHEN, E., I947. Body size and metabolic rate in animal kingdom with special regard to marine microfauna. C.R. Lab. Carlsberg, Ser. Chim., Vol. 26, pp. I7-16r. 